\title{
Cyclostratigraphy - concepts, definitions, and applications
}

\author{
by André Strasser, Frederik J. Hilgen, and Philip H. Heckel
}

with 15 figures

\begin{abstract}
Cyclostratigraphy is the subdiscipline of stratigraphy that deals with the identification, characterization, correlation, and interpretation of cyclic variations in the stratigraphic record and, in particular, with their application in geochronology by improving the accuracy and resolution of time-stratigraphic frameworks. As such it uses astronomical cycles of known periodicities to date and interpret the sedimentary record. The most important of these cycles are the Earth's orbital cycles of precession, obliquity, and eccentricity (Milankovitch cycles), which result from perturbations of the Earth's orbit and its rotational axis. They have periods ranging from 20 to $400 \mathrm{kyr}$, and even up to millions of years. These cycles translate (via orbital-induced changes in insolation) into climatic, oceanographic, sedimentary, and biological changes that are potentially recorded in the sedimentary archives through geologic time. Many case studies have demonstrated that detailed analysis of the sedimentary record (stacking patterns of beds, disconformities, facies changes, fluctuations in biological composition, and/or changes in geochemical composition) enables identification of these cycles with high confidence. Once the relationship between the sedimentary record and the orbital forcing is established, an unprecedented high time resolution becomes available, providing a precise and accurate framework for the timing of Earth system processes. For the younger part of the geologic past, astronomical time scales have been constructed by tuning cyclic palaeoclimatic records to orbital and insolation target curves; these time scales are directly tied to the Present. In addition, the astronomical tuning has been used to calibrate the ${ }^{40} \mathrm{Ar} /{ }^{39} \mathrm{Ar}$ dating method. In the older geologic past, "floating" astronomical time scales provide a high time resolution for stratigraphic intervals, even if their radiometric age is subject to the error margins of the dating techniques.
\end{abstract}

Because the term "sedimentary cycle" is used in many different ways by the geologic community and does not always imply time significance, we propose using "astrocycle" once the cycle periodicity has been demonstrated by a thorough cyclostratigraphic analysis.

Authors' addresses: AndrÉ STRASSER, Department of Geosciences, University of Fribourg, CH-1700 Fribourg, Switzerland, e-mail: andreas.strasser@unifr.ch; Frederik J. Hilgen, Faculty of Earth Sciences, University of Utrecht, 3584 CD Utrecht, The Netherlands, e-mail: fhilgen@geo.uu.nl; Philip H. Heckel, Department of Geoscience, University of Iowa, Iowa City, Iowa 52242, U.S. A., e-mail: philip-heckel@uiowa.edu 


\section{Introduction}

In an effort to present the state of the art in stratigraphic classification, the International Subcommission on Stratigraphic Classification (ISSC) of the International Commission on Stratigraphy (ICS), a member of the International Union of Geological Sciences (IUGS), publishes a series of articles on various stratigraphic concepts. This series is not meant to be a revision but rather a complement to the International Stratigraphic Guide (Hedberg 1976, Salvador 1994). In the case of cyclostratigraphy, a relatively young and rapidly developing subdiscipline in stratigraphy, no recommendations or definitions are offered in these guides. In the first edition of the Guide, "cyclothems" are mentioned among "other informal lithostratigraphic units" (HEDBERG 1976, p. 36). In the second edition of 1994, palaeoclimatic changes are listed under procedures for extending chronostratigraphic units as a potential tool for correlating chronostratigraphic boundaries away from the boundary stratotype, while carbonate and isotope cycles are mentioned in the glossary under chemostratigraphy (SALVADOR 1994). The present contribution therefore aims to summarize the concepts of cyclostratigraphy, to give some real world examples of the application of this stratigraphic tool, to show the potential and caveats of the method, and to propose a simple nomenclature.

Cyclostratigraphy uses astronomical cycles of known periodicities to interpret repetitive patterns in the sedimentary record. The basic principles of orbital forcing of Quaternary glaciations were first published by ADHÉmAR (1842) and Croll $(1864,1875)$ and later refined by Milankovitch $(1920,1941)$. Gilbert (1895) was the first geologist to apply cyclostratigraphic principles to the limestone-shale alternations in the Late Cretaceous Benton, Niobrara and Pierre groups in Colorado (U.S.A.), which he correctly interpreted to be controlled by the precession cycle. He thus accurately determined the duration of part of the Cretaceous just prior to the invention of radiometric dating. In 1910, DE GEER calculated geological time by counting varves deposited in proglacial lakes of Sweden, thus using the Earth's yearly revolution around the sun as a time unit. The stratigraphic cyclicity in the Eocene Green River Formation (Wyoming, U.S.A.) was analysed by BRADLEY (1929) who identified sunspot cycles as well as the precessional signal. SCHWARZACHER (1947) recognized a hierarchical rhythmicity in the Late Triassic platform limestones of the Dachstein in Austria ("Lofer cycles") and suggested a control by the precession cycle and the short eccentricity cycle, a theme that FIscher took up again in 1964. In the Pleistocene, oxygen isotopes have been used to trace ocean temperature and ice volume changes and to establish a scale implicitly linked to orbital cycles (e.g., Emiliani 1955, Shackleton \& Opdyke 1973, Hays et al. 1976). A more detailed summary of the history of cyclostratigraphy is given by FiscHer et al. (2004).

The term "cyclostratigraphy" was probably first introduced at a meeting of the Global Sedimentary Geology Program held in Perugia (Italy) and Digne (France) in 1988 (FISCHER et al. 1988). Cyclostratigraphy can now be defined as "the subdiscipline of stratigraphy that deals with the identification, characterisation, correlation, and interpretation of cyclic (periodic or nearly periodic) variations in the stratigraphic record and, in particular, with their application to geochronology by improving the accuracy and resolution of time-stratigraphic frameworks" (HILGEN et al. 2004). Although cyclical or periodic 
processes cover the wide range from twice-daily tidal cycles to plate-tectonic movements with recurrences of tens of millions of years (House 1995), the cycles most commonly used in cyclostratigraphy are those caused by the perturbations in the Earth's orbit and in the inclination of its axis (Milankovitch cycles). Due to the numerous high-resolution climate studies of the Late Pleistocene and the Holocene, increasing attention is now being paid to cycles in the sub-Milankovitch band of the spectrum with periods of 1 to 15 kyr (e.g., Heinrich events and Dansgaard-Oeschger cycles) and to cycles that occur on annual, decadal and centennial time scales. The analysis of cycles related to tides, to the annual revolution of the Earth, or to sunspot activity can provide a very high time resolution in sedimentary and ice core records. However, these higher frequency cycles are rarely described from older time intervals and are rarely preserved over more than a few thousand years. They are therefore not the focus of the present paper.

A glossary for commonly used astronomical, geological, and statistical terms is added as an annex.

\section{From astronomical cycles to the sedimentary record}

The movement of the Earth around the Sun and the inclination of its axis are subject to quasiperiodic perturbations caused by the gravitational pull of the Sun, the Moon, and the planets. Today, the eccentricity of the ellipse of the Earth's orbit varies with major periods of $\sim 100$ and $\sim 400 \mathrm{kyr}$, and the obliquity of the Earth's axis varies with a main period

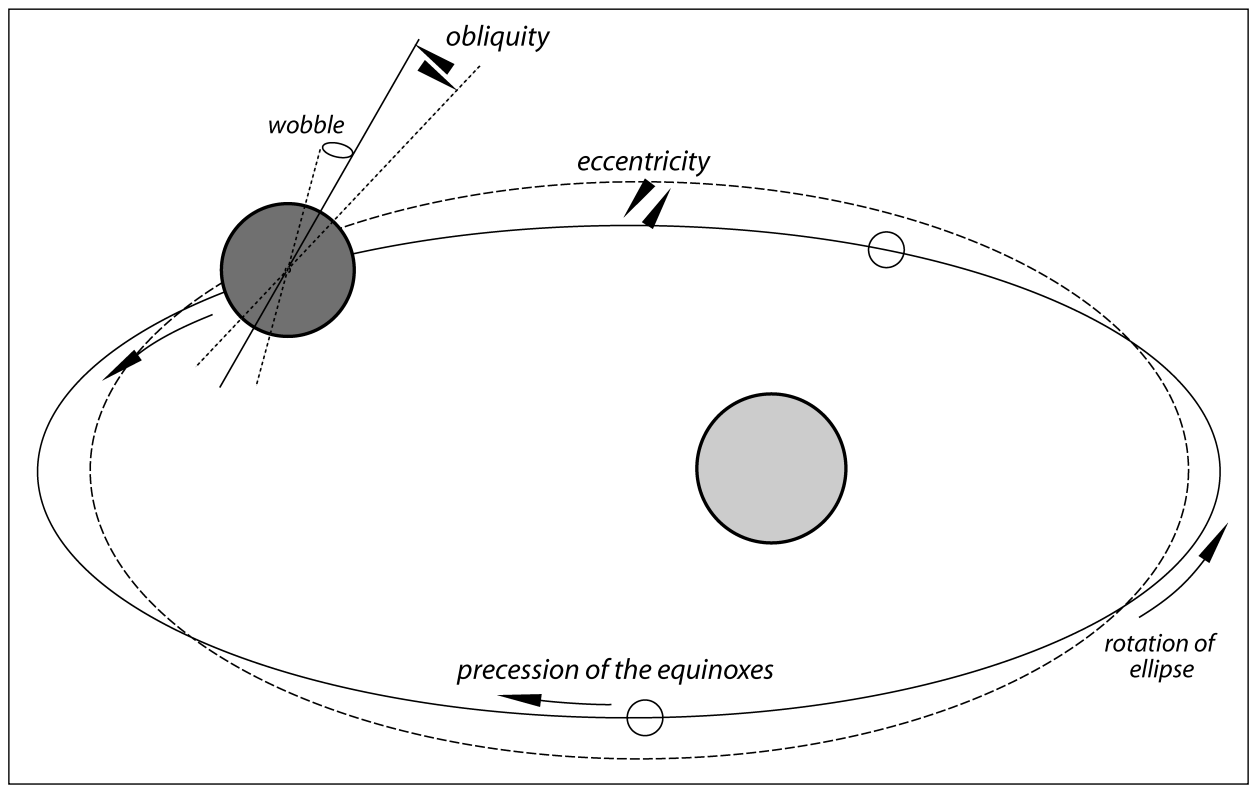

Fig. 1. Astronomical variables that control insolation on Earth (based on Pisias \& IMbRIE 1986). 
of about $41 \mathrm{kyr}$ and secondary periods of $\sim 29$ and $\sim 54 \mathrm{kyr}$. The combination of the precession of the Earth axis (wobble) relative to the stars with a period of $\sim 26 \mathrm{kyr}$ (termed astronomical precession) and the rotation of the ellipse of the Earth's orbit in opposite direction produces the precession of the equinoxes relative to perihelion and aphelion (climatic precession) with main periodicities of around 19 and $23 \mathrm{kyr}$ (BERGER 1978, SCHWARZACHer 1993; Fig. 1). Finally, very long-period orbital components (i. e., 1.2 myr in obliquity and 2.4 myr in eccentricity; HILGEN et al. 2003) exist but they may be difficult to identify in the sedimentary record because they occur on longer ("tectonic") time scales, which are often dominated by tectonic processes overprinting the climatic signal.

Although the orbital changes are not truly cyclical but quasi-periodic, it is commonly accepted by the geological community to speak of "orbital cycles" or of "Milankovitch cycles". Because the distance between Earth and Moon has gradually increased over geologic time, the obliquity and precession cycles have been significantly shorter in the past (Berger et al. 1989, 1992, but see also Williams 1991, 2000; Fig.2). The eccentricity cycles, however, have remained relatively stable. Although the solar system has a chaotic behaviour (LASKAR 1989), the calculated values are nevertheless precise enough to allow for a detailed comparison with the stratigraphic record (BERGER et al. 1992). The Earth's orbital parameters are calculated with the help of astronomical solutions for the Solar System, which also solve the Earth-Moon system. Following the first linearized solutions of French astronomers such as Le Verrier, analytical solutions became increasingly accurate by adding higher-order terms related to the disturbing planetary masses and to the planetary eccentricities and inclinations (e.g., BERGER 1977). The newest solutions of VARADI (2003) and LASKAR et al. (2004) are fully numerical in part to overcome the chaotic behaviour of the Solar System. The VARAdi (2003) solution does not resolve the Earth-Moon

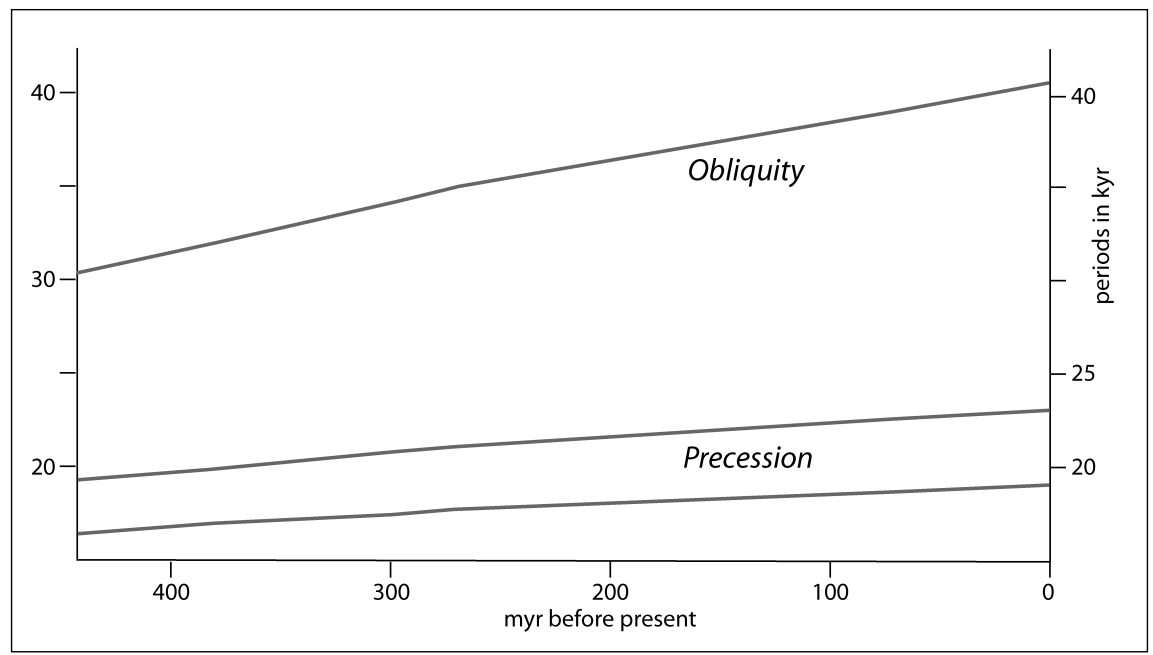

Fig. 2. Change of periodicities of obliquity and precession cycles with geologic time (based on BERGER et al. 1989). 


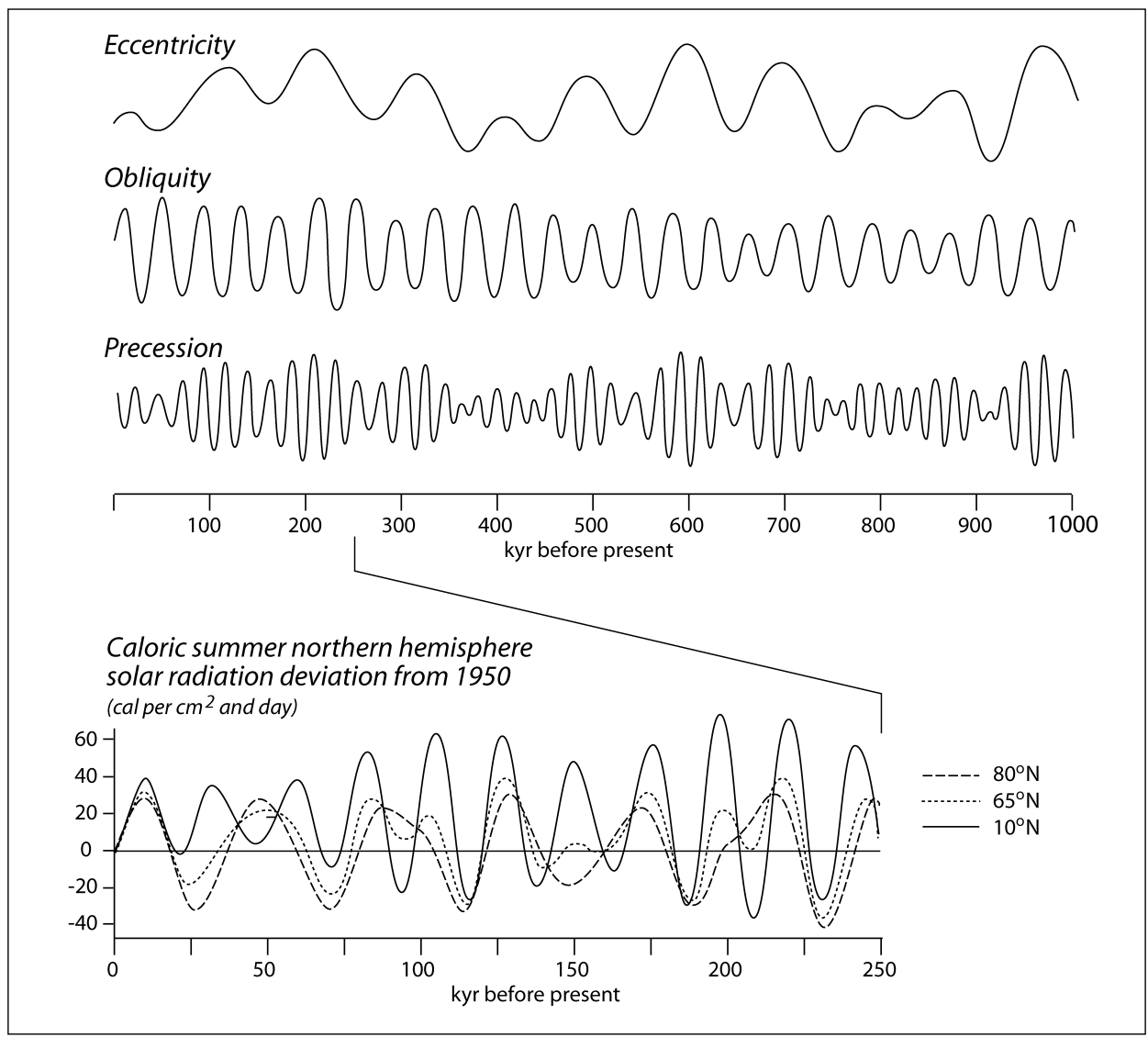

Fig. 3. Indices for eccentricity, obliquity, and precession for the last million years (adapted from SCHWARZACHER 1993), and variability of insolation in function of latitude for the last $250 \mathrm{kyr}$ (adapted from BERGER 1978).

system and hence cannot be used to calculate precession and obliquity. The eccentricity of both these solutions is almost identical and reliable over the last 40 million years.

The orbitally induced changes in the Earth-Sun distance and in the inclination of the Earth's axis result in changes in the insolation received by the Earth at the top of its atmosphere, which translate into climate changes (BERger 1978, Schwarzacher 1993; Fig. 3). Insolation changes influence the position of the atmospheric circulation cells and provoke latitudinal shifting of climatic belts (MatTHews \& PerLmutter 1994). Climate then influences many parameters that, directly or indirectly, control sediment production, transport, and accumulation (Fig. 4).

Atmospheric temperature and circulation changes translate into changes of water temperature, oceanic circulation, and rainfall pattern. The activity of glaciers, rivers, and wind 


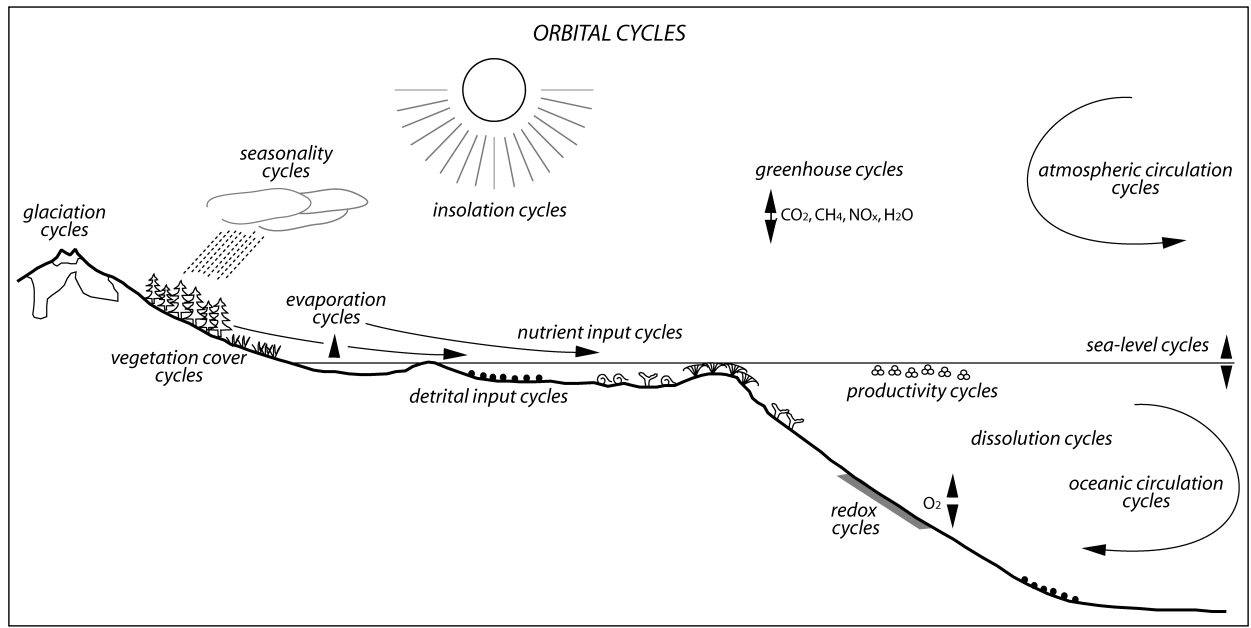

Fig. 4. Sketch illustrating the complexity of the atmospheric, oceanic, sedimentary, and biological system that is influenced by orbitally induced insolation changes. Frequencies and amplitudes of the different "cycles" vary strongly and may be out of phase.

as well as the vegetation cover control sediment production and transport from land to ocean. Freshwater and nutrient input through rivers, evaporation, deep ocean or lake circulation, and gas exchange between the water surface and atmosphere influence the water chemistry. All these intimately linked factors eventually control the organic and inorganic sediment production as well as the geochemical signatures. Depending on the sensitivity of the sedimentary and biological systems, several of these parameters may be recorded and thus indirectly reflect the orbital parameters. Some proxy records translate the astronomical forcing in an almost perfect linear way (e. g., Ti/Al ratios in an Eastern Mediterranean core monitor climatically controlled input of aeolian dust; Lourens et al. 2001). However, considering the complexity of many sedimentary and biological systems, it cannot be expected that the orbital cycles always translate one-to-one into the sedimentary record.

A major controlling factor on sedimentary systems is eustatic sea level. During icehouse periods, high-amplitude sea-level changes are created through the waxing and waning of polar ice-sheets and mountain glaciers. The resulting sea-level changes are strongly asymmetric because ice-sheets melt faster than they grow. This asymmetry is well known from the oxygen-isotope proxy record of the Late Pleistocene (Hays et al. 1976). In greenhouse periods, the fluctuating volume of small mountain glaciers (FRAKES et al. 1992), thermal expansion and retraction of the uppermost layer of ocean water (GORNITZ et al. 1982), thermally-induced volume changes in deep-water circulation (Schulz \& SchäFer-Neth 1998), and/or water retention and release in lakes and aquifers (Jacobs \& SAHAgIan 1993) may contribute to low-amplitude sea-level changes. Eustatic sea level, together with subsidence, controls accommodation. Consequently, a 
sedimentary sequence created by an orbitally controlled sea-level fluctuation can potentially be interpreted in terms of sequence stratigraphy (VAIL et al. 1991, STRASSER et al. 1999).

The challenge now is to analyse the sedimentary record and to search for signals that reflect orbital control. If such a signal is detected, then a relatively precise time framework can be established, within which rates of climatic, oceanographic, sedimentary, biological, and diagenetic processes can be evaluated. This signal may consist of stacked deepeningshallowing facies sequences such as seen on shallow platforms, of limestone-marl alternations in the hemipelagic realm, of periodic faunal and floral changes, of repetitive geochemical changes, or of a combination of such phenomena. It is clear that astronomical climate forcing is most accurately recorded in depositional settings where the preservation potential is highest (deep marine basins, rapidly subsiding shelves, long-lasting deep lakes). Its influence on turbidity currents, rivers, or alluvial fans remains to be investigated. It is outside the scope of this paper to cite all publications that illustrate such cyclical deposits. Case studies (as well as excellent introductions to the principles of cyclostratigraphy) are given in Einsele et al. (1991), DE Boer \& SMITH (1994), House \& GALE (1995), and D'ArgENio et al. (2004).

\section{Concepts and methodologies}

In their quest for the absolute and accurate timing of pre-Quaternary Earth history, geochronologists employ a multitude of methods that all have advantages and disadvantages (e. g., BERGGREN et al. 1995). Among these methods, cyclostratigraphy holds a particular position. It is not based on the radioactive decay of isotopes measured in minerals but uses astronomical cycles of known durations as clockwork. The prerequisite for the application of this method is, of course, the recognition of patterns in the sedimentary record that can confidently be linked to astronomical cycles. Such patterns include repetitive sedimentary, biological, and/or geochemical changes as proxies of repetitive processes in the geosphere-hydrosphere-biosphere-atmosphere system, which were themselves controlled by orbitally induced insolation changes. In order to optimally extract repetitive patterns from the sedimentary record, detailed logging of the studied sections or cores is indispensable, and the sections or cores must be as complete as possible. Other tools have to be chosen as a function of the type of sediment (e. g., microfacies, micropalaeontological, grain-size, $\gamma$-ray, magnetic susceptibility, stable-isotope, trace-element, organic-matter, colour analyses).

Many studies have successfully demonstrated that orbital cycles are indeed recorded and can be used to improve the timing of Earth history. Commonly, two methods are combined to obtain a trustworthy result:

1. Independent time control is needed to constrain the time interval in which the cyclostratigraphical study is conducted. This can be done by direct radiometric age dating, or through biostratigraphy, chemostratigraphy, magnetostratigraphy, and/or sequence stratigraphy calibrated to radiometric age dates. Even if the error margins are large, the average duration of a sedimentary cycle can roughly be estimated and serve as a starting point for further analysis. 
2. Analysis of the bierarchical stacking pattern. For Phanerozoic sediments it can be assumed in a simplified way that the precession of the equinoxes corresponds to $20 \mathrm{kyr}$, and the short and long eccentricity cycles to 100 and $400 \mathrm{kyr}$, respectively. These periods then give rise to a 1:5:20 ratio for which the stratigraphic record can be analysed. For obliquity, and to a lesser extent also for precession, the periodicity has to be selected based on the geological age of the studied sediments (Fig. 2).

For the cyclostratigraphic analysis of shallow carbonate platforms, "Fischer plots" are sometimes employed (e.g., Read \& Goldhammer 1988, Sadler 1994). The assumption is that each sedimentary cycle has the same time duration, that subsidence was constant, and that accommodation space was always filled up to the intertidal zone (the thickness of one sedimentary cycle thus corresponds to the accommodation created during one sea-level fluctuation). The resulting curve serves as a proxy of relative sea-level changes that might reflect an orbital signal. However, if the sediment does not fill in the available space ("subtidal cycles" of OsLeger 1991) and/or if compaction has varied according to facies, Fischer plots will not be a reliable proxy of sea-level changes.

In order to test for the expected ratios between the orbital periodicities, time-series analysis is commonly applied. The choice of the measured parameters and the sampling density are crucial for such an analysis to be successful (FISCHER et al. 2004). Stratigraphic gaps have to be identified and accounted for. Lateral changes of bed thicknesses and facies are common in shallow-water environments. In deeper-water environments, slumping, sliding, and/or current activity may locally disturb the sedimentary record. Cyclostratigraphic analysis of one measured and sampled section therefore is not sufficient, and it is necessary to study several laterally correlated sections and create a synthetic composite section for time-series analysis.

A critical aspect of time-series analysis in cyclostratigraphy is the conversion of the initial record from the depth domain into the time domain using age calibration points; the latter may be derived from radiometrically dated ash layers or dated bio-events, or from magnetostratigraphic calibration to the geomagnetic polarity time scale. Once the time series is established, different techniques such as Fourier analyses, wavelet analysis, or neural-net-aided detection can be employed to detect orbital periodicities (e. g., BREsCiA et al. 1996, Weedon \& Jenkyns 1999, Hinnov 2000, Preto et al. 2004, ZüHlke 2004). The classic way to detect frequency components in a time series is Fourier spectral analysis. Fourier analysis is used to decompose a time series into a sum of sinusoids with specific frequencies, amplitudes, and phases. The outcome of the Fourier analysis is usally shown in the frequency domain in the form of a spectrum, which gives the distribution of variance (power) of a time series as a function of frequency. The spectrum is of great interest because many natural phenomena have variability that is frequency-dependent, and understanding the frequency dependence may yield critical information about the underlying mechanisms. One of the main drawbacks of Fourier-based spectral methods is that the outcome is presented in the frequency domain (as a frequency spectrum) and not in the time domain so that it is impossible to tell which spectral components (or cycles) occur at which time in the time series. However, there are ways to circumvent this short-coming in Fourier analysis, namely bandpass filtering and the application of Win- 
dowed Fourier Analysis, which results in an evolutive (or moving) spectrum. An alternative solution to the problem is to apply wavelet analysis because it gives information both in the time and frequency domains as a time-frequency representation of the signal. Note that spectral analysis can also be applied in the depth domain, giving the period of cycles in meters and not in years. A comprehensive overview of time-series analysis applied to cyclostratigraphy is presented by WEEDON (2003).

Once a Milankovitch signal has been identified in the stratigraphic record and the sedimentary, biological, or geochemical cycles have been attributed to specific orbital cycles, an attempt can be made to reconstruct the astronomical forcing of climate change. Moreover, for the younger part of the stratigraphic record, astronomical time scales can be established by tuning the orbitally controlled proxy cycles to astronomical target curves derived from astronomical solutions of the Solar System. Such time scales have an unprecedented accuracy and resolution.

Three case studies are presented, each from a different area, with a different geologic age, and from a different depositional setting.

\section{Cenozoic case study: astronomical time scale for the Mediterranean Neogene}

During the Neogene, the Mediterranean became a semi-enclosed basin due to the ongoing collision between Africa/Arabia and Europe. The basin was particularly sensitive to record astronomically induced climate changes due to its land-locked character in combination with its latitudinal position between the (semi-)arid Sahara/Sahel belt to the south and the area influenced by the Atlantic system (westerlies) to the north. The best known sedimentary expression of these climate changes in the Mediterranean are sapropels. Sapropels are dark coloured, commonly well-laminated beds enriched in organic matter, which occur frequently in deep marine successions of Late Neogene age. Sapropels reveal cyclic patterns on various scales, the cycle hierarchy reflecting the superimposed astronomical climate forcing by the Earth's orbital parameters of precession, obliquity, and eccentricity. Basin confinement played an important role because the oldest sapropels are most likely linked to the final closure of the eastern gateway to the Indian Ocean around 14-15 Ma, while the Middle Miocene climate cooling (dated astronomically at $13.8 \mathrm{Ma}$; oxygen isotope event Mi-3b) and associated glacio-eustatic sea-level lowering (ABELs et al. in press) may have played an additional role. The change in the lithological expression of the sedimentary cycles in the latest Miocene provides another clue that basin configuration is important: the normal marl-sapropel alternations are replaced by tripartite marlsapropel-diatomite cycles and finally by evaporite (gypsum) cycles in the course of the Messinian Salinity Crisis, when the open-marine connection of the Mediterranean with the adjacent Atlantic became severely disrupted (e.g., KrIJGSMAN et al. 1999).

Individual sapropels and related carbonate-marl alternations represent the basic (elementary) units in the cycle hierarchy. These basic cycles usually occur in small-scale clusters containing 4 to 6 basic cycles; the small-scale clusters in turn are grouped into larger-scale clusters, which comprise 3 to 4 small-scale clusters. Finally, successive basic cycles may reveal alternating thick-thin-thick patterns. Independent age control provided by oxygen-isotope chronology, magnetostratigraphy, and calcareous plankton 


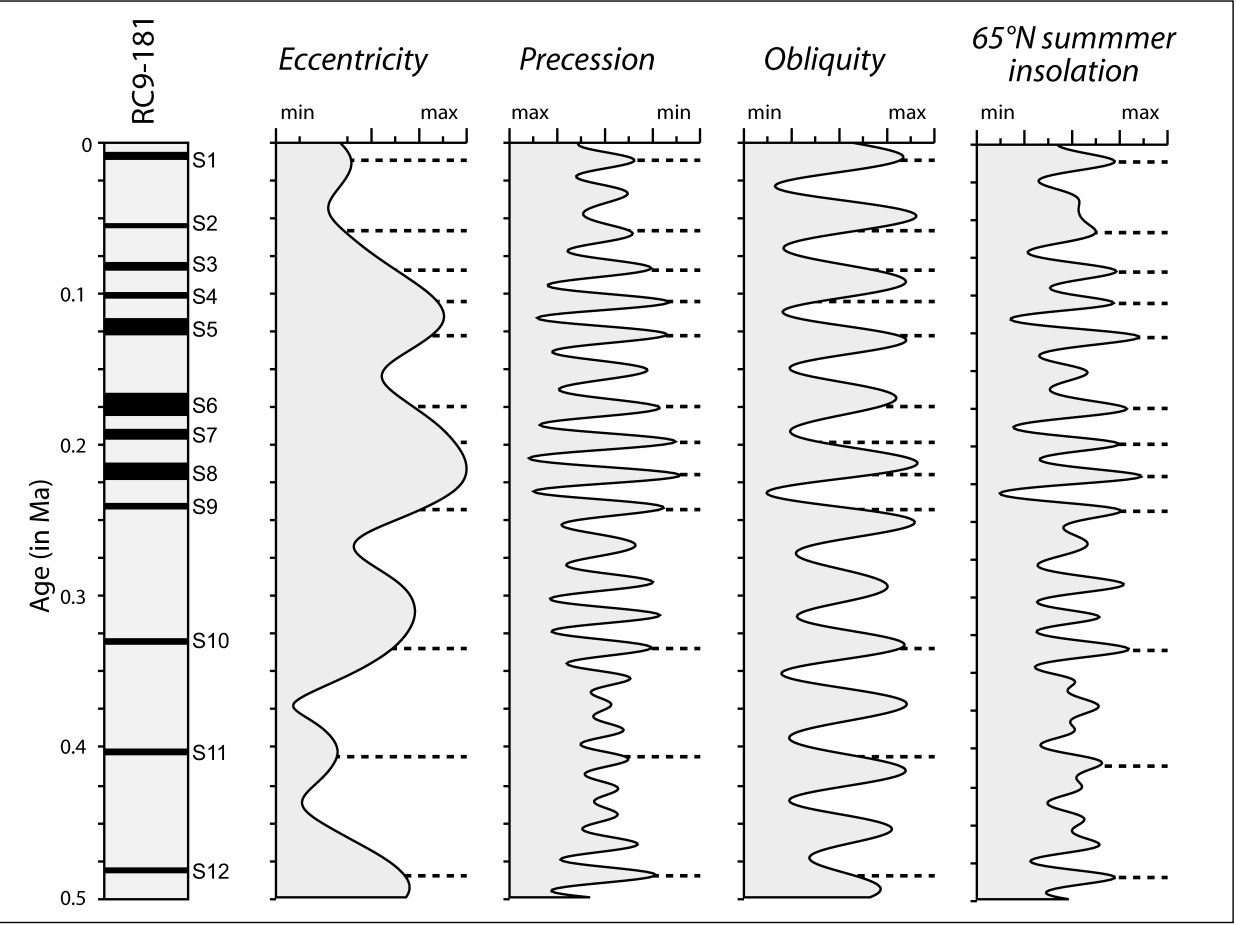

Fig. 5. Comparison of the sapropel chronology of the last 0.5 million years in the Mediterranean with the calculated time series for the changes in the Earth's orbit, the inclination axis and the summer insolation for $65^{\circ} \mathrm{N}$. This comparison reveals the phase relations between the sapropels and the orbital parameters (modified after HiLgen 1991, LouRENs et al. 1996). The length of core RC 9-181 is slightly more than $9 \mathrm{~m}$.

biochronology all point to a precessional origin of the basic cycle. The small-scale and large-scale clusters then correspond to the 100- and 400-kyr eccentricity cycles (HILGEN 1991), while alternating thin-thick cycles reflect the additional influence of obliquity or more precisely precession-obliquity interference (LouRENs et al. 1996). Such interference patterns dominate the sapropel record every 2 to $2.5 \mathrm{myr}$, while the small-scale clusters reflecting the 100-kyr eccentricity cycle are distinctly lacking at the same time. The recurrence of these patterns corresponds to the influence of the very long-period 2.4 myr eccentricity cycle (Hilgen et al. 2003).

Phase relations between the sapropel cycles and the orbital parameters have been established by examining the youngest sapropels of Late Pleistocene and Holocene age that were recovered in numerous piston cores from the eastern Mediterranean (HILGEN 1991, Lourens et al. 1996). This comparison reveals that individual sapropels correspond to precession minima when (boreal) summer solstice is reached in perihelion; small-scale and large-scale sapropel clusters correspond to 100 - and 400-kyr eccentricity maxima, 


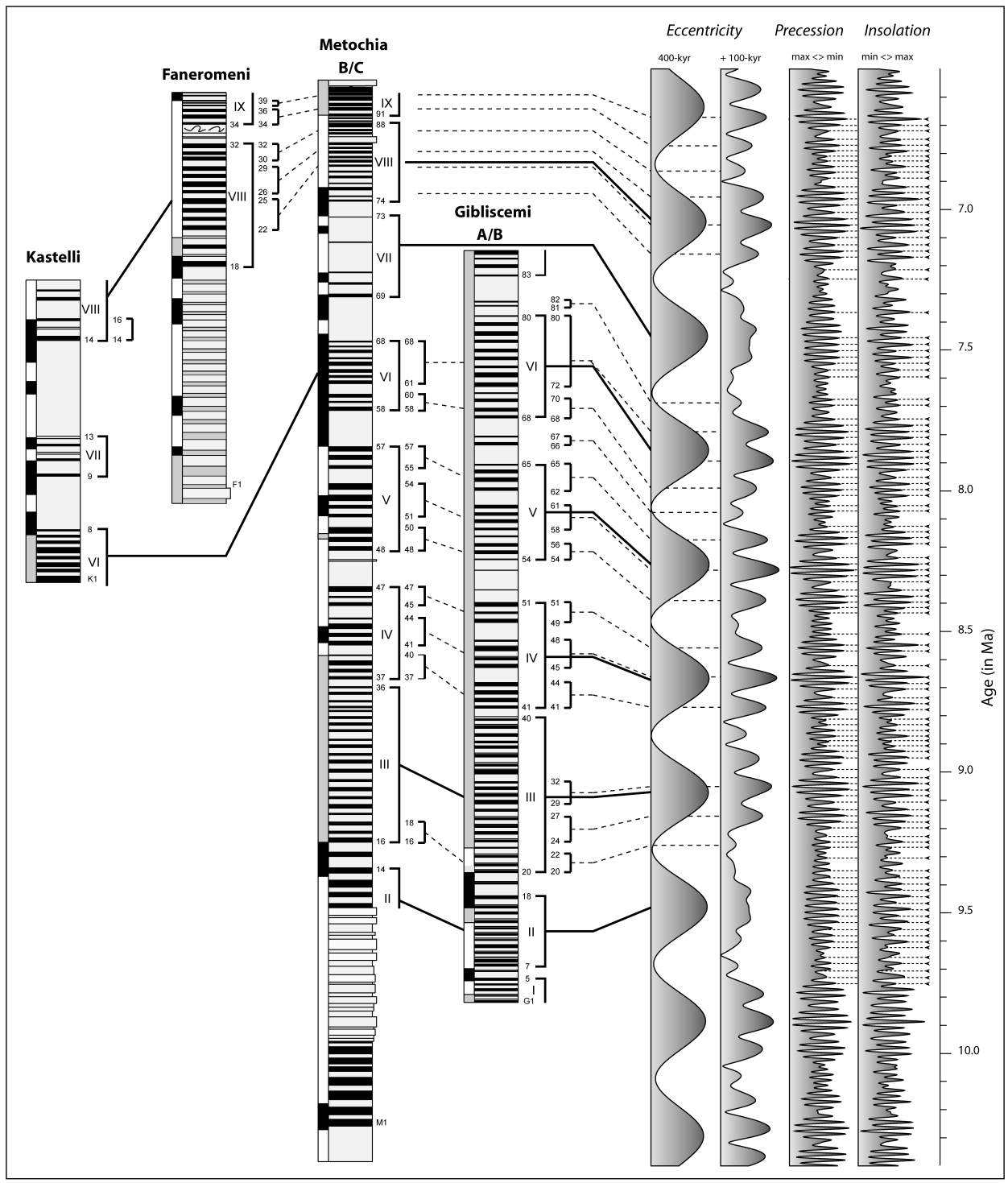

Fig. 6. Astronomical tuning of sapropels of late Miocene age in the Mediterranean (between 6.7 and $9.8 \mathrm{Ma}$ ) to the astronomical target curves using the phase relations determined in Figure 5 (modified after Hilgen et al. 1995). Following an initial magnetostratigraphic and biostratigraphic age control, the tuning was established by correlating first the large-scale sapropel clusters - marked by Roman numerals I to IX - to successive 400-kyr eccentricity maxima. Next small-scale sapropel clusters were correlated to $100-\mathrm{kyr}$ ecccentricity maxima and individual sapropels to precession minima and summer insolation maxima. 
respectively (Fig. 5). Finally, the thicker sapropels in the thick-thin-thick alternations correspond to obliquity maxima. These phase relations were subsequently used to correlate or tune older sapropels and carbonate cycles to the astronomical target curves of precession, obliquity and eccentricity, or of summer insolation (Figs. 6, 7). This tuning process typically proceeds according to the following steps: (1) initial age constraints are provided

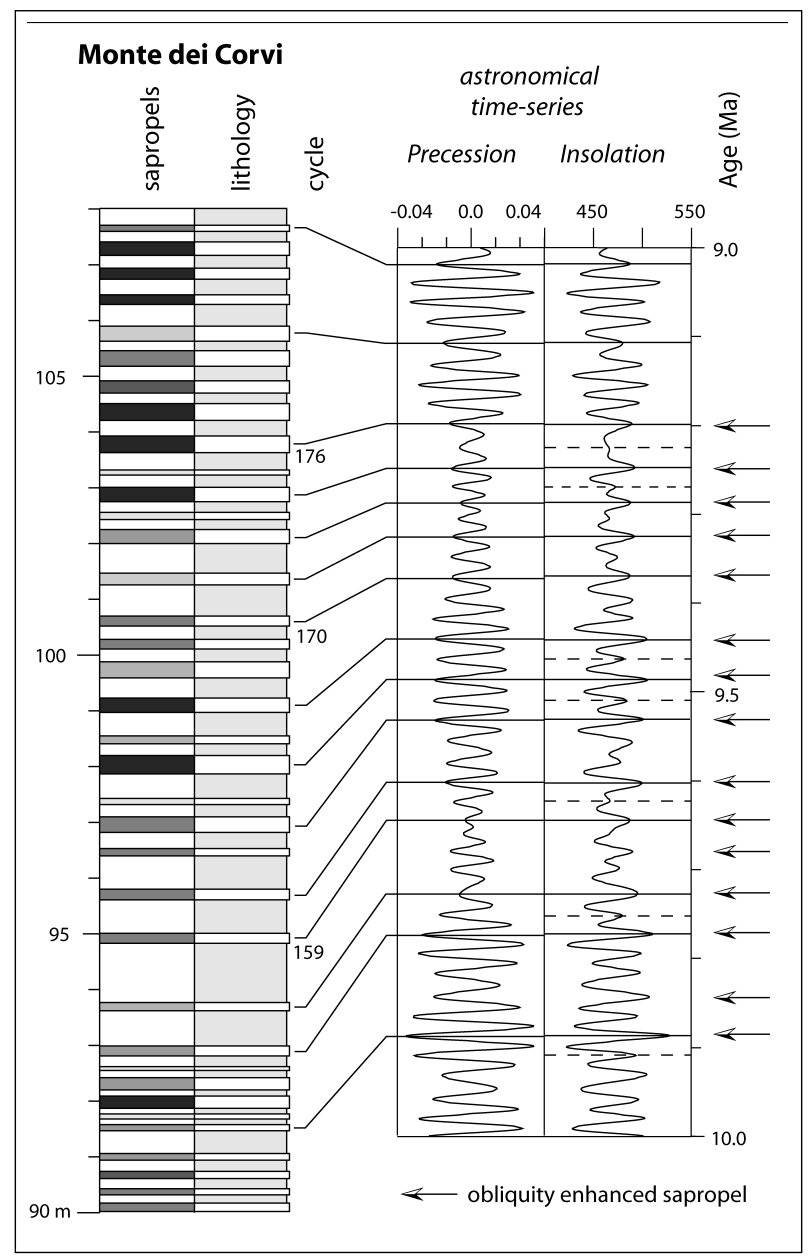

Fig. 7. Comparison of intricate details in sapropel patterns related to precession-obliquity interference for the interval between 9 and $10 \mathrm{Ma}$ in the Monte dei Corvi section (northern Italy) with the $65^{\circ} \mathrm{N}$ summer insolation target curve of solution $\mathrm{La} 93_{(1,1,1}$, i. e. with present-day values for dynamical ellipticity and tidal dissipation. The comparison remains essentially the same for the new La2004 solution. Arrows mark a perfect correspondence between relatively thick and distinct sapropels and obliquity enhanced summer insolation maxima. Note that the sapropel patterns have been checked in parallel sections elsewhere in the Mediterranean. 
by an integrated stratigraphic approach (calcareous plankton biostratigraphy, magnetostratigraphy); (2) initial tuning is based on correlating the larger-scale cycles, i.e. the sapropel clusters, to successive 400- and 100-kyr eccentricity maxima; and (3) final tuning is based on correlating individual sapropels to successive precession minima or associated summer insolation maxima.

The tuning of deep-marine sapropel-containing successions in the Mediterranean has now been completed for the interval covering the last 14 million years. It provides very precise and accurate ages not only for the sedimentary cycles but also for calcareous plankton events and magnetic polarity reversals recorded in the tuned sections. The tuning resulted in an astronomical time scale for the Mediterranean Late Neogene with an unprecedented accuracy and resolution. This time scale includes a polarity reversal history based on the astronomical ages for calibrated reversal boundaries (Fig. 8).

In fact, sapropels provide such an accurate and precise recording of astronomical climate forcing that they have been used to determine which astronomical solution is more accurate from a cyclostratigraphic point of view (HILGEN et al. 1993). Moreover, cycle patterns in climate proxy records have been used to determine exact values of tidal dissipation and dynamical ellipticity (Lourens et al. 2001); these two parameters are included in astronomical solutions of LASKAR but cannot be calculated from the solution itself because they depend on Earth processes such as glaciations. Finally, ${ }^{40} \mathrm{Ar} /{ }^{39} \mathrm{Ar}$ ages of ash layers within tuned sapropel-bearing sections have been used to intercalibrate the independent radiometric and astronomical dating methods and to establish an astronomical age for mineral dating standards used in ${ }^{40} \mathrm{Ar} /{ }^{39} \mathrm{Ar}$ dating (KuIPER et al. 2004).

Despite their application in constructing high-resolution time scales, the climatic processes leading to the deposition of sapropels are still not fully understood. Terrestrial derived climate proxies such as chemical element ratios and clay minerals reveal clear drywet oscillations with sapropels deposited during the humid phase of the climate cycle (e.g., Wehausen \& Brumsack 2000, Foucault \& Melières 2000). Their formation is often linked to intensification of the African monsoon (and related pluvials on the northern African continent) due to enhanced summer heating at times of precession minima, resulting in increased Nile outflow and reduced deep water formation as a consequence of water column stratification, eventually leading to anoxic bottom waters. In fact, the enhanced freshwater flux to the basin may even result in a reversal from anti-estuarine to estuarine circulation. However, palaeoclimate studies and climate modelling of orbital extremes suggest that regional precipitation changes in the northern borderlands and net evaporation across the basin, which are mainly driven by the Atlantic winter system, may be equally or even more important. Unfortunately, deep water formation itself is very difficult to model (Myers 2002, Tuenter 2004). In addition, it is still unclear to what extent productivity changes contributed to sapropel formation. Increased productivity at times of sapropel formation may have resulted from the higher nutrient flux to the basin, enhanced winter mixing as a consequence of the increase in seasonal contrast (LouRENS et al. 1992), shoaling of the pycnocline into the photic zone (RoHLING 1991), and/or a reversal in circulation.

In the Mediterranean, continental successions have also been subjected to detailed cyclostratigraphic analysis, including astronomical tuning. This holds in particular for 


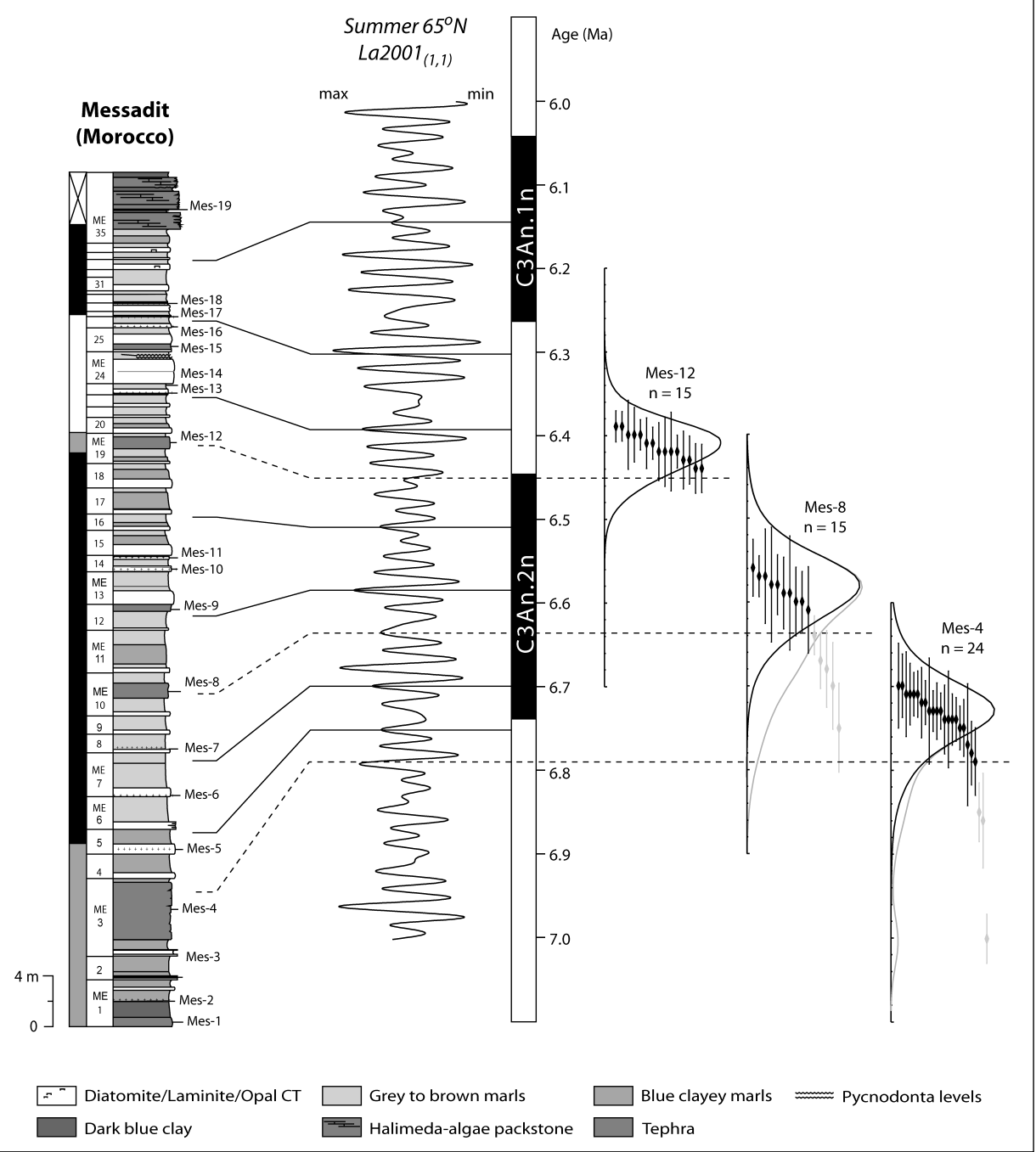

Fig. 8. Comparison between ${ }^{40} \mathrm{Ar} /{ }^{39} \mathrm{Ar}$ and astronomical ages for ash layers in the Messâdit section located on the Mediterranean side of Morocco. Astronomical tuning of the sedimentary cycles to the summer insolation target is shown, with the tuning starting from astronomical ages for planktonic foraminiferal bioevents exported from other sections in the Mediterranean (after vaN AsseN et al. 2004). Also shown is the calibration of the magnetostratigraphy to the Astronomical Polarity Time Scale. Examples of cumulative ${ }^{40} \mathrm{Ar} /{ }^{39} \mathrm{Ar}$ age probability distribution curves and individual single crystal sanidine age determinations are shown for three ash layers to the right of the polarity column. Grey curves show age distribution based on all individual single crystal measurements; black solid curves show preferred age distribution excluding (older) outliers indicated by grey diamonds that are considered reworked (contaminants). Finally the ${ }^{40} \mathrm{Ar} /{ }^{39} \mathrm{Ar}$ ages are compared with the astronomical ages for the same ash layers (dashed lines). 
cyclic lacustrine successions of Pliocene-Pleistocene age in Greece (Mommersteeg et al. 1995, vAN VUGT et al. 1998) and for distal alluvial fan to floodplain-lacustrine limestone sequences of Miocene age in Spain (e.g., Abdul AzIz et al. 2003). The Miocene and Pliocene studies reveal a dominant precession control on lake level, although - similar to sapropels - an additional obliquity signal is found in Spain. Such studies allow detailed cyclostratigraphic correlations between the marine and continental realms and the reconstruction of the influence of astronomical climate forcing along marine to continental environmental gradients (e. g., van VugT et al. 1998; TzEDAKIs et al. 2003).

Apart from unravelling the climatic origin of the cyclicity, the tuned time scale combined with a high-resolution integrated stratigraphic approach helped already solving many fundamental problems in the Neogene, such as those related to the origin of the Messinian salinity crisis (MSC) when huge amounts of evaporites were deposited in the Mediterranean. Evidently, the onset of evaporite formation at $5.96 \mathrm{Ma}$ occurred synchronously in the western, central and eastern Mediterranean (KRIJGSMAN et al. 1999). This onset is not related to glacial cyclicity and associated glacio-eustatic sea-level lowering but to tectonic closure of the gateway with a superimposed imprint of the 400-kyr eccentricity cycle (KrijgSman et al. 2004). Similarly, the gypsum cycles in the Lower Evaporites were not controlled by glacio-eustatic sea-level changes related to the dominantly obliquity-controlled glacial cyclicity but to dominantly precession-controlled changes in regional climate. Finally, the end of the MSC marked by the Pliocene flooding of the Mediterranean is not associated with a major deglaciation as previously thought (VAN DER LAAN et al. 2006).

\section{Mesozoic case study: platform to basin correlation in the Early Cretaceous of the Jura Mountains}

During the Berriasian, the area of today's Swiss and French Jura Mountains was part of the northern passive margin of the Tethys Ocean (Ziegler 1988). Palaeolatitude was about 32 to $33^{\circ} \mathrm{N}$ (Dercourt et al. 2000). Carbonate productivity was high: in the platform interior, shallow lagoons harboured abundant carbonate-producing organisms such as green algae, bivalves, gastropods, ostracodes, foraminifera, and echinoderms. Microbes produced oncoids. Coral patch reefs occurred sporadically. Ooid shoals developed mainly on the platform margin. Extensive tidal flats formed when carbonate production filled in accommodation space, and islands emerged when sea level dropped. Freshwater lakes with charophytes appeared locally. Periodically, fine quartz sand and clays were washed into this generally carbonate-dominated system. At the same time, in the Vocontian Basin in France, limestone-marl alternations developed in a hemipelagic setting (PASQUIER 1995, HiLlgäRTNER 1999).

Fourteen platform sections and 4 basinal sections have been logged, sampled, and interpreted in great detail by PASQUiER (1995) and HillgärTner (1999). Facies analysis was carried out to identify the depositional environments, and bedding surfaces were analysed to estimate the relative duration of hiatuses (HILLGärTNER 1998). In the platform sections, facies evolution shows repetitive deepening-shallowing trends that define elementary depositional sequences with thicknesses of a few tens of centimetres to a few 


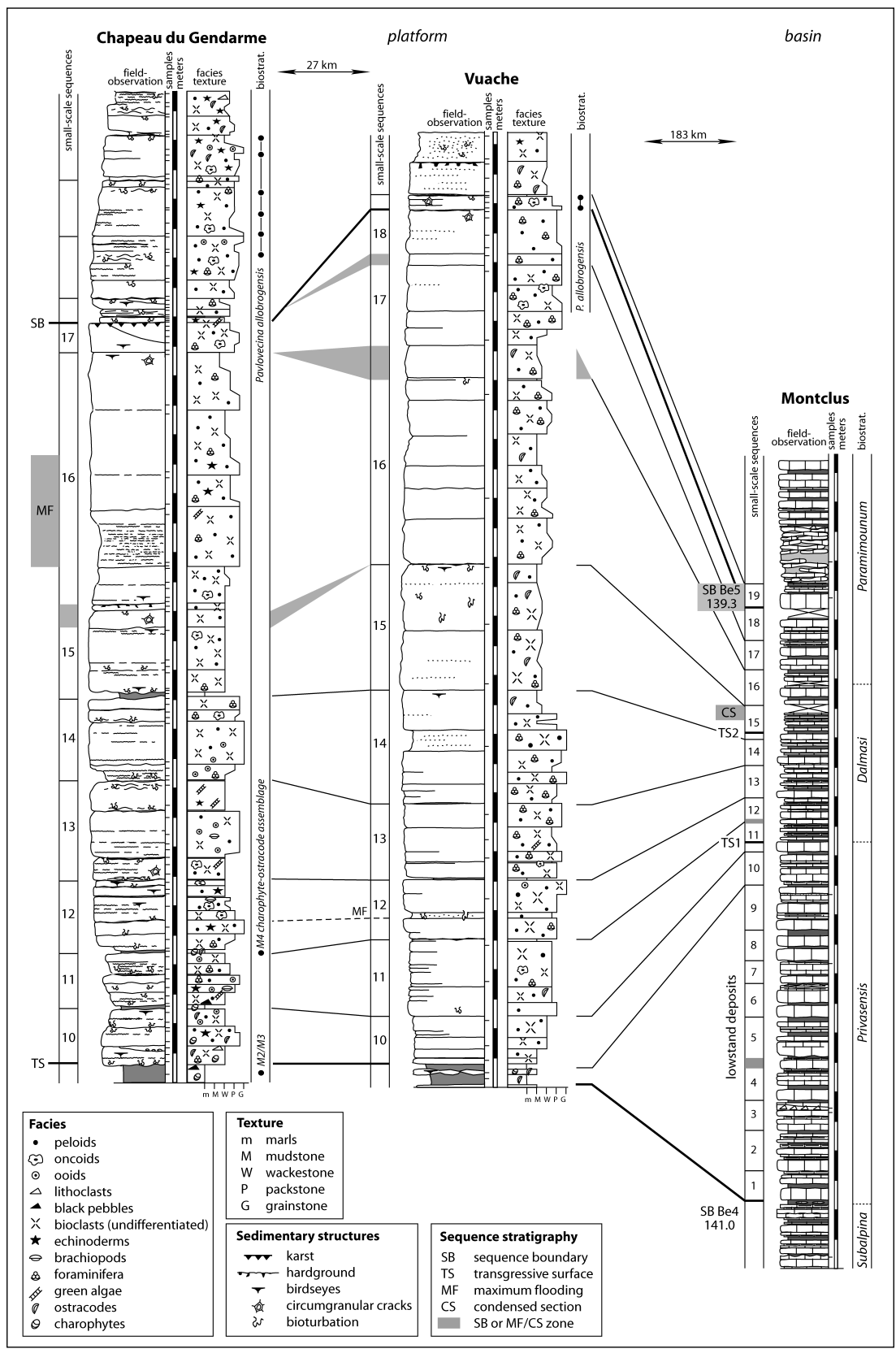

Fig. 9. Stratigraphic logs from two selected platform sections in the French Jura and from one basin section in the Vocontian Trough. Correlation, sequence-and cyclostratigraphic interpretation. For explanation refer to text. 
metres. They commonly form individual beds. The elementary sequences group into small-scale sequences, which again display a general deepening-shallowing trend and have thicknesses of a few metres. These sequences then build up medium-scale sequences, which in turn form large-scale sequences of a few tens of metres of thickness. The stacking of these sequences is hierarchical: between 2 and 6 elementary sequences build up a small-scale sequence, and 4 small-scale sequences form a medium-scale one. Large-scale sequences are bounded by prominent, regionally correlatable surfaces and comprise 2 to 4 medium-scale sequences. In the basinal sections, limestone-marl couplets are the elementary building blocks. On the average, five such couplets group into bundles that display a thickening-up trend. Slumps locally disturb this regular pattern. For the purpose of this paper, only one interval exposed in two platform sections and one basinal section is illustrated as an example of stacking of sequences and of platform-to-basin correlation (Fig. 9). A more complete documentation and analysis is given in STRASSER et al. (2004).

In the basinal sections, the biostratigraphic framework is established by ammonites (Le Hegarat 1971). On the platform, Clavel et al. (1986) found some rare ammonites, which imply that the Subalpina subzone is strongly condensed. The benthic foraminifer Pavlovecina allobrogensis found in the studied sections (Fig. 9) can be attributed to the Paramimounum subzone (CLAvel et al. 1986). The charophyte-ostracode assemblage M2/M3 belongs to the Subalpina subzone, while the M4 assemblage indicates the Privasensis and Dalmasi subzones (DÉTrAz \& Mojon 1989). Within this biostratigraphic framework, the sections can now be interpreted in terms of sequence stratigraphy. On the platform, the transgressive surface of the illustrated large-scale sequence leads from lacustrine marls to marine limestones. Maximum flooding is indicated by the thickest beds (suggesting highest accommodation). The following sequence boundary is defined by birdseyes, circumgranular cracks, and karst. In the basin, a large-scale sequences boundary is placed at the base of a series of relatively thick limestone beds at the boundary between the Subalpina and Privasensis subzones. It can be correlated with sequence boundary Be4 of Hardenbol et al. (1998), which has been recognized also in other European basins. Two transgressive surfaces (TS1 and TS2, Fig. 9) are identified in the basin where there are rapid changes from more limestone-dominated to more marl-dominated intervals. The condensed section is suggested by the most marly part of the large-scale sequence. The base of a thick limestone bed below a slumped interval is interpreted to correspond to sequence boundary Be5 of Hardenbol et al. (1998), situated in the Paramimounum subzone.

In the basinal section, 92 limestone beds grouped into 19 bundles are counted between Be4 and Be5. According to Hardenbol et al. (1998), based on the radiometric dating by GradsteIn et al. (1995), the time span between these sequence boundaries is about 1.7 myr (Fig. 10). The average durations of a limestone-marl couplet and of a bundle can thus be estimated at $18 \mathrm{kyr}$ and $89 \mathrm{kyr}$, respectively. These values and the systematic bundling suggest that they correspond to the precession cycle of $20 \mathrm{kyr}$ and to the short eccentricity cycle of $100 \mathrm{kyr}$, respectively. The discrepancy between the average duration calculated from the dated sedimentary record and the durations of the orbital cycles is not surprising, considering (1) that the radiometric ages have large error margins (e.g., the Tithonian-Berriasian boundary is dated at 144.2 $\pm 2.6 \mathrm{Ma}$ by GradsTeIN et al. 1995, respectively $145.5 \pm 4.0 \mathrm{Ma}$ by GRADSTEIN et al. 2004), (2) that the sedimentary record 
may include hiatuses and/or autocyclically formed beds, and (3) that the age calibration of the sequence stratigraphy of HARDENBOL et al. (1998) is based on ammonite zones that sometimes have ill-defined boundaries.

The rough biostratigraphic framework allows for the correlation of the large-scale sequence (between sequence boundaries Be4 and Be5) from basin to platform (Fig. 9). This correlation also suggests that one small-scale sequence on the platform is the equivalent of a bundle in the basin and, consequently, formed in harmony with the short eccentricity cycle. The small-scale sequences are generally well defined through facies and surfaces, but in some cases it is advantageous to introduce a sequence-boundary zone that covers an interval of time where accommodation was low (STRASSER et al. 1999). The elementary sequences are often difficult to identify in the platform sections. Autocyclic processes may be superimposed, sequences may be hidden if a sea-level change did not create a facies contrast, or sequences may be missing through non-deposition or erosion at the boundaries of small-scale sequences. Figure 11 illustrates the formation of hidden sequence boundaries and of sequence-boundary zones. Where five elementary sequences build up a small-scale sequence, it can be assumed that they correspond to the precession cycle (STRASSER et al. 2004).

Medium-scale sequences are difficult to identify in the sections shown in Fig. 9 but are visible in many other sections studied by PAsquier (1995) and Hillgärtner (1999). They commonly display an overall deepening-shallowing facies trend and consist of four small-scale sequences. Consequently, they are attributed to the long eccentricity cycle of

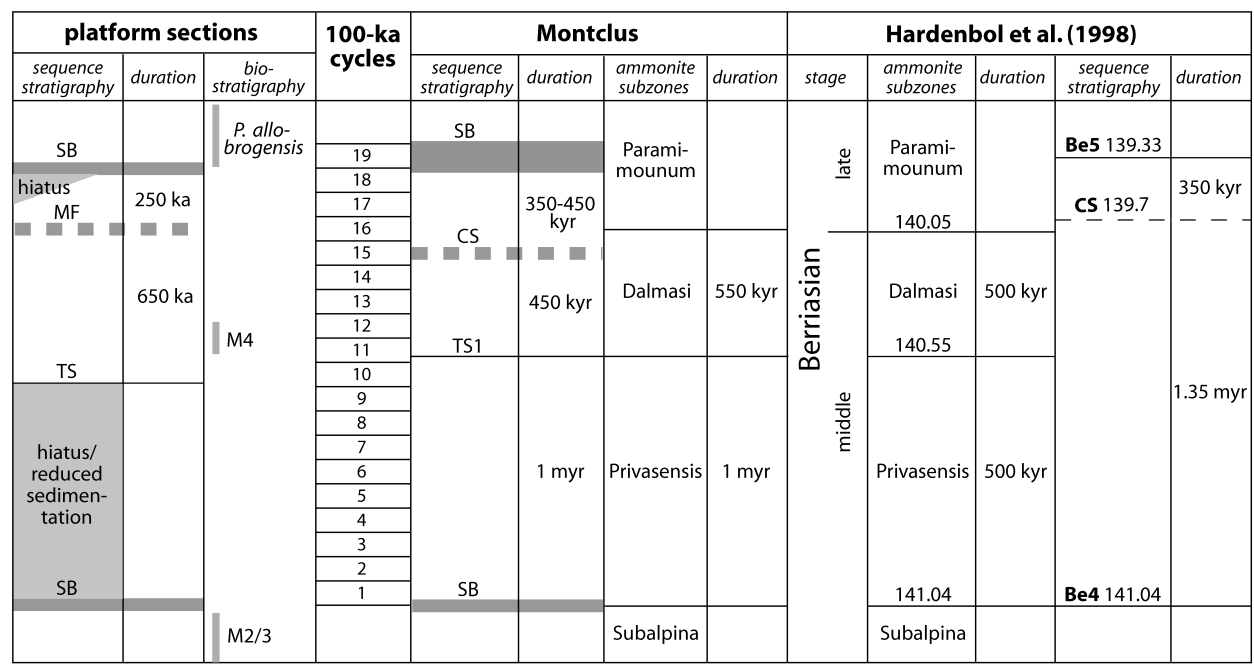

Fig. 10. Comparison of the sequence- and cyclostratigraphic interpretation according to Fig. 9, and comparison with the sequence-chronostratigraphic chart of HARDENBOL et al. (1998). For discussion refer to text. SB: sequence boundary, TS: transgressive surface, MF: maximum flooding, CS: condensed section, Be4 and Be5: sequence boundaries according to HARDENBOL et al. (1998) with ages in million years. 


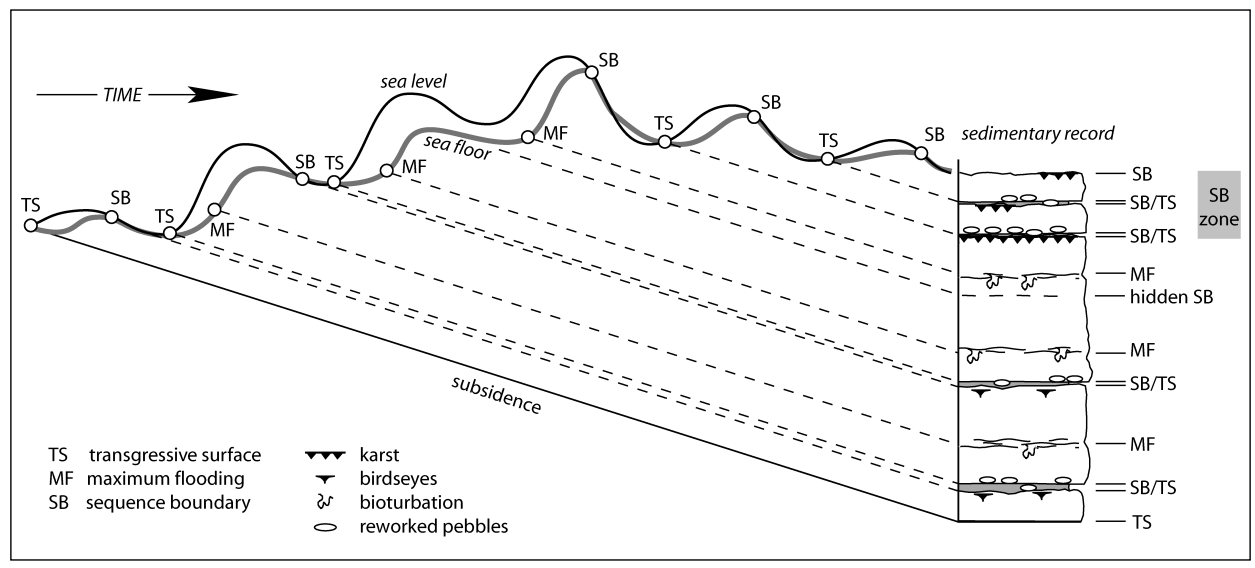

Fig. 11. Formation of hypothetical elementary and small-scale depositional sequences by two superimposed frequencies of sea-level fluctuations in shallow-water carbonate systems. After emersion, a certain lag time is needed before carbonate production starts up and sediment accumulates. When sea-level drops below the sediment surface, erosion occurs for some time, then cementation sets in, and the sediment surface is lowered by chemical dissolution. For simplification, the sedimentary record is not compacted. Modified from STRAsser et al. (2004).

$400 \mathrm{kyr}$. Large-scale sequences have prominent sequence boundaries and are composed of several medium-scale sequences. They correspond to the third-order sequences of VAIL et al. (1991). In some cases their boundaries are tectonically enhanced, in other cases they reflect multiples of the long eccentricity cycle (STRASSER et al. 2000). Because of tectonic overprinting, the very long orbital cycles (1.2 and $2.4 \mathrm{myr}$ ) could not be identified in the present study. However, these cycles are supposedly present in other shallow carbonate platforms successions (e.g., García et al. 1996).

From the combination of detailed sequence-stratigraphic and cyclostratigraphic analysis it becomes possible to estimate the duration of the hiatus at the base of the platform sections. The correlation with the basin suggests that it lasted $900 \mathrm{kyr}$. Also, it is interesting to note that the platform started being flooded by marine waters while in the basin typical lowstand conditions with the formation of thick limestone beds prevailed for another $100 \mathrm{kyr}$ (Fig. 9). The physical expression of condensation due to relatively fastest sea-level rise appears in sequence 15 in the basin, while maximum accommodation on the platform occurs in sequence 16 . In the Chapeau de Gendarme section, the karst surface at the top of sequence 17 must have lasted at least $100 \mathrm{kyr}$, during which time sequence 18 was deposited at Vuache. Furthermore, the durations of ammonite zones can be better defined. While the cyclostratigraphically implied duration of the Dalmasi subzone is consistent with the value given by HARDENBOL et al. (1998), there is a large discrepancy concerning the Privasensis subzone (Fig. 10). It would be important to study well-dated sections from other basins and to discuss this point with biostratigraphers.

On the shallow platform, the main parameter for the formation of depositional sequences was sea level, which was controlled by orbitally driven climate changes. The 
high-frequency, low-amplitude sea-level cycles were probably more or less symmetrical because they were controlled rather by thermal expansion of the ocean water than by glacio-eustasy (READ 1995). Humid-dry climate cycles could have been responsible for periodically increased input of clay minerals into the basin, and/or for periodic productivity changes of the calcareous plankton that makes up a large part of the carbonate fraction in the limestone-marl couplets (EINSEle \& Ricken 1991, PAsQuier \& STRAsser 1997, Pittet \& Mattioli 2002). Sea-level changes had only an indirect influence on basin sedimentation, for example by controlling the export of carbonate mud from the platform to the basin (Pittet \& Strasser 1998, Pittet \& Mattioli 2002).

\section{Palaeozoic case study: Pennsylvanian cycles in midcontinent North America}

During late Middle and Late Pennsylvanian time (Desmoinesian, Missourian, and Virgilian regional stages, closely equivalent, respectively, to late Moscovian, Kasimovian, and Gzhelian global stages), the Midcontinent, Illinois, and Appalachian basins were slowly subsiding across central and eastern U.S.A. in the tropical trade wind belt of that time. These shallow basins were connected westward (currently southwestward) through deeper narrow basins in central Oklahoma and west Texas to the Panthalassan/Protopacific Ocean. At maximum sea-level lowstand during this time of widespread Gondwanan

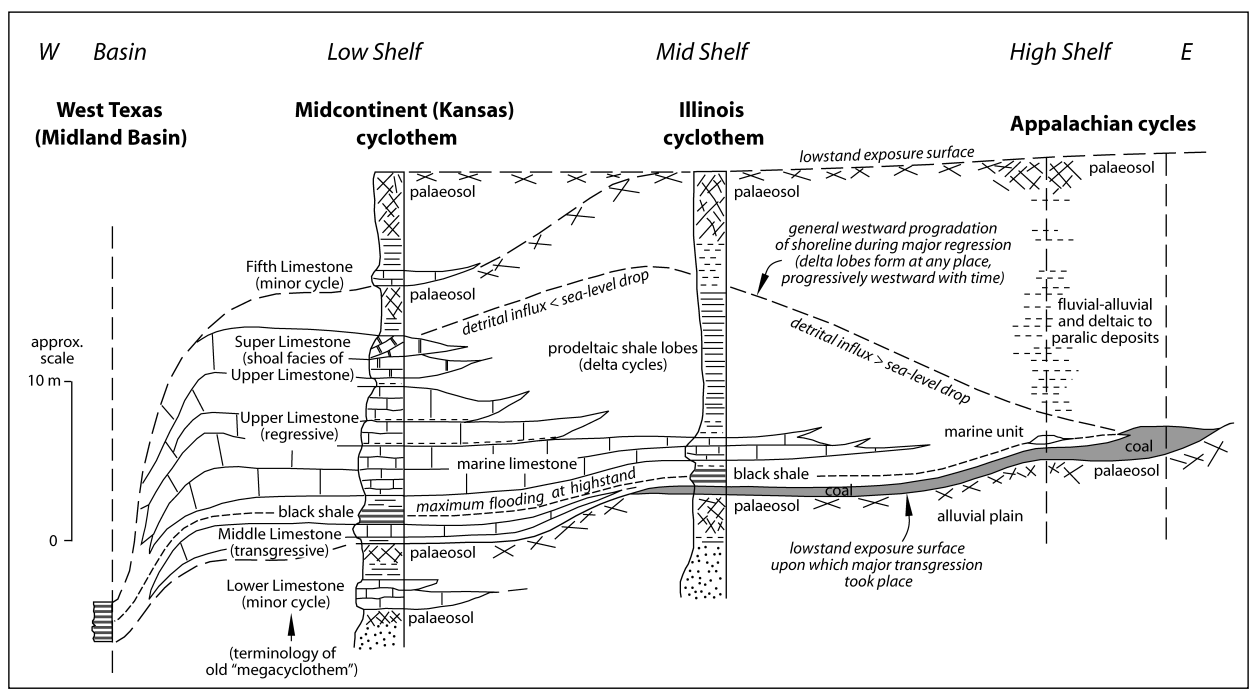

Fig. 12. General lithic facies developed in a major Late Pennsylvanian glacio-eustatic cyclothem across region from Midcontinent through Illinois to Appalachian basins (low to high shelf) where the unit is generally bounded by exposure surfaces (from Heckel 1994). Two minor cyclothems are shown above and below the major cyclothem on the lower shelf. Basin shown to west is distant Midland Basin of west Texas where marine deposition of anoxic shale facies was continuous through this time. 
glaciation, the Appalachian and Illinois basins and the northern three-quarters of the Midcontinent Basin (Northern Midcontinent Shelf) were subaerially exposed, as indicated by widespread exposure surfaces with palaeosols and terrestrial deposits. At maximum sea-level highstand, marine deposits sandwiched between the exposure surfaces extended across all three basins. These deposits were dominated by shales with sandstones and thin limestones in the Appalachian basin adjacent to the Appalachian orogenic belt, by shales with some sandstones and slightly thicker limestones in the Illinois Basin, and by thick limestones with thin shales on the Northern Midcontinent Shelf (Fig. 12). They grade southward into a thicker succession of shale and sandstone in the foreland basins of central Oklahoma as the limestones pinch out approaching the Ouachita orogenic belt.

The term "cyclothem" was introduced by WANLESS \& WeLLER (1932) for the transgressive-regressive depositional units of this succession in the Illinois Basin, and it was soon extended to the more complex units on the Northern Midcontinent Shelf by R. C. Moore (see summary in Heckel 1984). These units were attributed to the waxing and waning of Gondwanan glaciation by WANLESS \& SHEPARD (1936); additional support for this interpretation was provided by Heckel (1986, 1994, 2002a), among others. The empirical relative sea-level curve constructed from field and core data along the midcontinent outcrop belt (Fig. 13) shows the succession of transgressions and regressions on various scales. Within this succession, $\operatorname{HeckeL}(1986,1994)$ classified individual cyclothems along the Midcontinent outcrop belt as "major", "intermediate", and "minor", based on their relative scale as deduced from both their continuity along outcrop and the deepest-water facies developed at the northern limit of outcrop in Iowa toward the ancient cratonic shoreline.

Major cyclothems are characterized by a widespread conodont-rich black phosphatic shale (the offshore or "core" shale) as the deepest-water facies, lying above a deepeningupward transgressive limestone and below a shallowing-upward regressive limestone. This black shale developed only during the most important flooding phases when anoxia as well as sediment starvation developed on the sea bottom because surface circulation no longer affected the bottom of the sea, and a quasi-estuarine circulation pattern with upwelling developed as the trade winds moved the surface waters offshore. Intermediate cyclothems contain only gray conodont-rich offshore shales or non-algal skeletal packstones, which represent sediment starvation without anoxia in shallower water, yet which was still deep enough for the unit to be continuous to the current northern limit of outcrop. Minor cyclothems either extend only partway onto the shelf, or they represent reversal of sea-level trends in the more major cyclothems (and thus are termed simply "cycles"). The latter type corresponds to "parasequences" in sequence-stratigraphic terminology (VAN WAGONER et al. 1990). The former type typically lacks conspicuously conodont-rich zones or other evidence of sediment starvation, whereas the latter type contains conodont-rich zones where it brings sediment-starved facies above shallowerwater, sediment-diluted facies. Basinward, all disconformities disappear, and even major cyclothem boundaries are marked by deeper-water conodont-rich, sediment-starved facies lying upon shallower-water, conodont-poor facies.

At maximum flooding, the sea was continuous across the entire central and eastern U.S.A. as shown by the great similarity of all marine faunas, particularly the conodonts, 


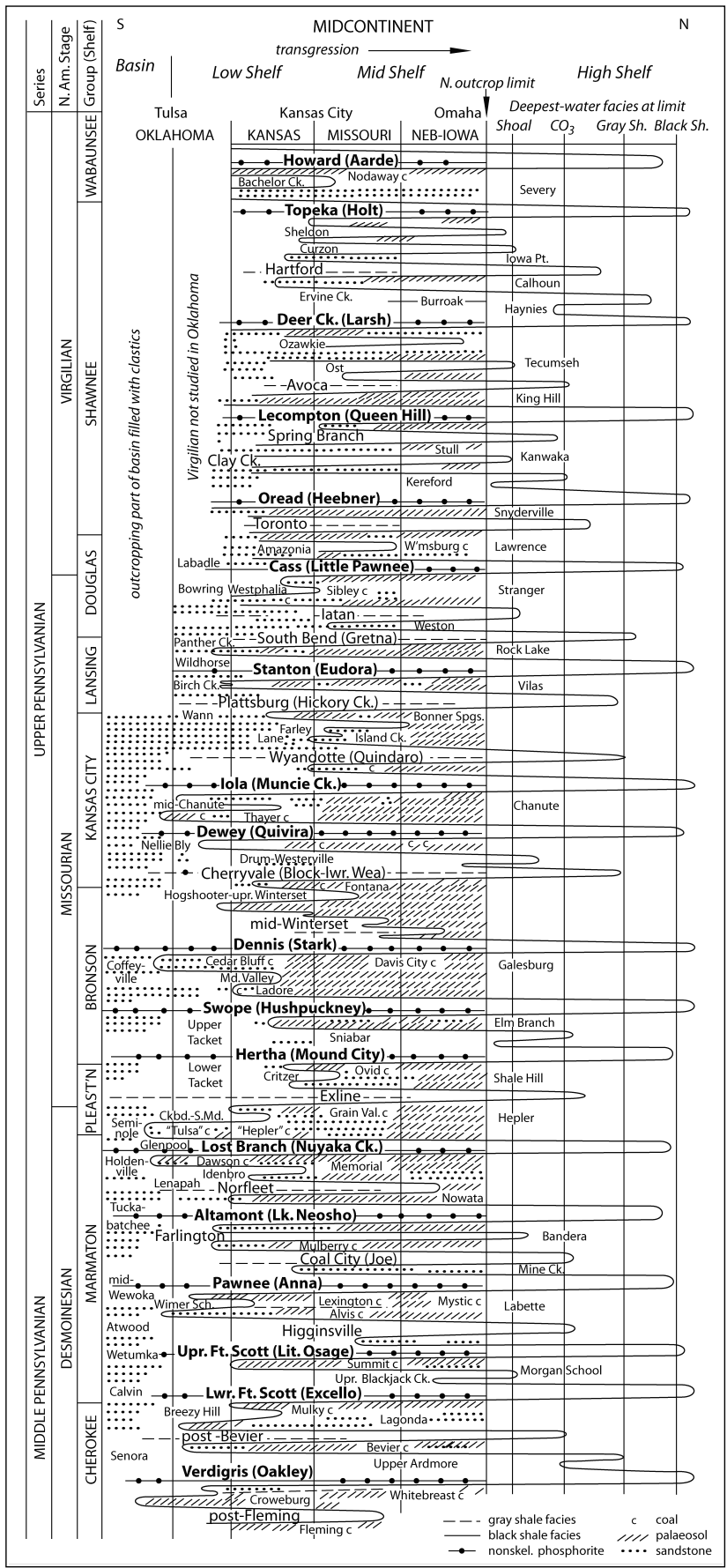

Fig. 13. Relative sea-level curve for the mid-Desmoinesian through mid-Virgilian succession showing all scales of cyclothems, classified as major, intermediate, or minor, based on lateral extent from Oklahoma foreland basin onto the shelf and on deepest water facies at the current northern limit on the shelf. Relative scale is denoted by decreasing letter size of names. Where present, offshore (core) shale names are in parentheses (updated from Heckel 1994). 
which allow an accurate correlation of the major cyclothems (Fig. 14). Shelf direction is shown by (1) the progressive loss of minor cyclothems from the foreland basin margin in Oklahoma northward along the midcontinent outcrop belt, (2) the loss of many intermediate cyclothems eastward into the Illinois Basin, and (3) ultimately the loss of all intermediate and some major cyclothems farther eastward in the Appalachian Basin, which at this time appears to have been a high shelf adjacent to the orogenic belt. Most recently, Heckel et al. (2005) have correlated the midcontinent cyclothems with those now recognized in the Moscow Basin on the Russian Platform and in the Donets Basin, using a combination of cyclothem scale and conodont and fusuline faunas.

The empirical relative sea-level curve for the midcontinent shelf (Fig. 13) shows that major cyclothems are spaced somewhat evenly throughout the succession, that most of them overlie widespread exposure surfaces, and that most are overlain by one or more intermediate or minor cycles following a regression of much less distance than the trans-

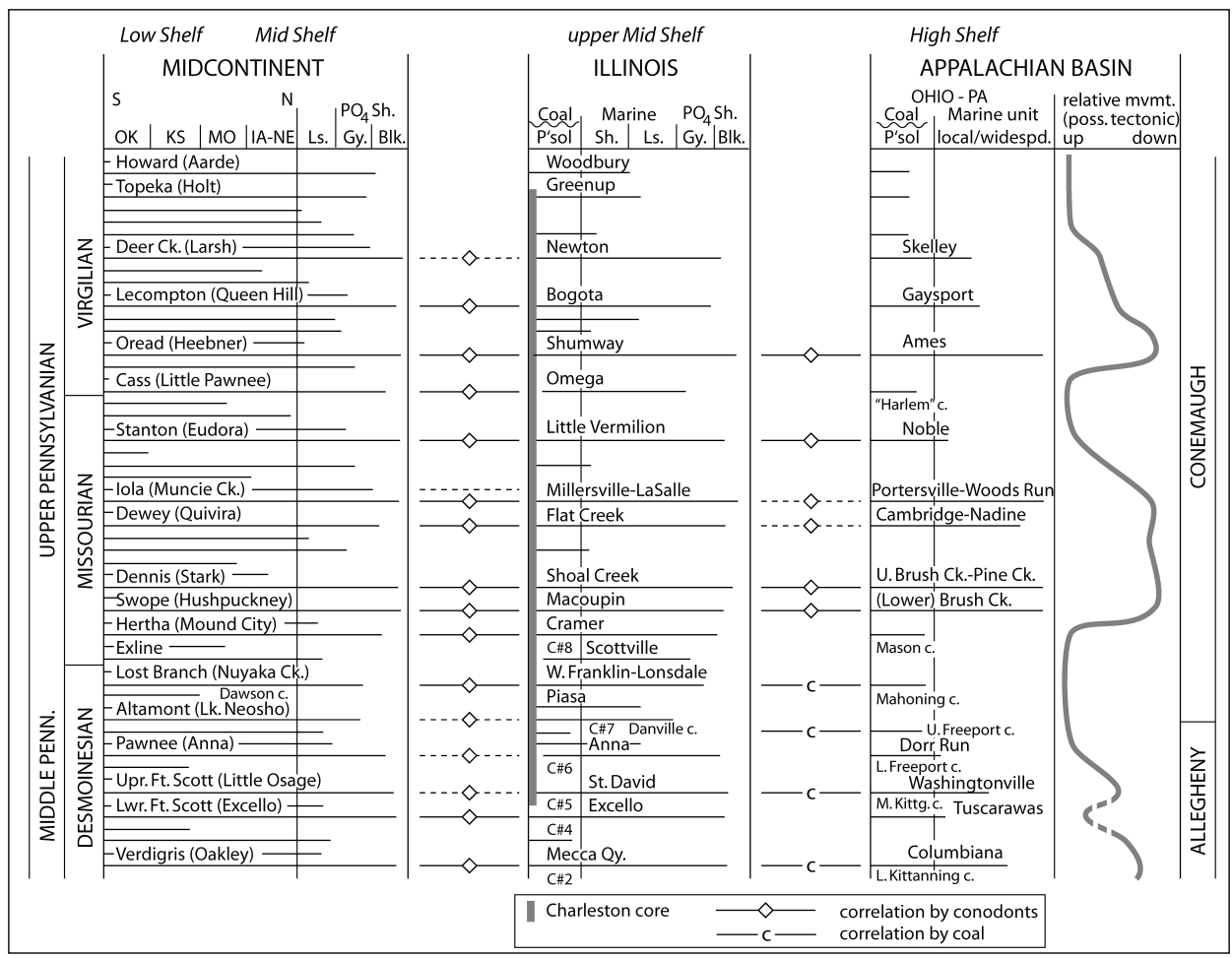

Fig. 14. Correlation of major midcontinent cyclothems (longest horizontal lines with cyclothem name above line followed by offshore shale name in parentheses) summarized from Figure 13, with those in Illinois and Appalachian basins, based on succession of conodont faunas along with coal correlations of Peppers (1996). Curve on right shows longer-term, probably tectonic relative subsidence curve with 2-myr period (updated from Heckel 1994). 
gression preceding the major cyclothem. This pattern is somewhat similar to that seen in the Pleistocene sea-level curve (e. g., Lorius et al. 1993): it reflects rapid meltdown of ice sheets (transgression) followed by slower buildup of ice sheets (regression) with episodic minor melting phases before reaching maximum sea-level lowstand.

There are as yet no discernable patterns of numerical groupings of 5 minor cycles that could readily be related to precession groupings within short eccentricity cycles, or groupings of 3 minor cycles that could be related to the $\sim 32-\mathrm{kyr}$ Pennsylvanian obliquity cycles (Fig. 2) within short eccentricity cycles. However, as minor cycles are still being discovered with continuing field and laboratory work, the data are not yet complete. Where the data are more complete among the larger cyclothems, there seems to be no consistent pattern of 4 intermediate cycles that could be related to short eccentricity groupings within long eccentricity cycles. Therefore, the empirical curve of Figure 13 appears to represent an irregular integrated manifestation of the interaction of all the orbital parameters filtered through complex climate changes severe enough to result in build-up and meltdown of large glacial ice sheets across large parts of the Gondwanan continent, which was modulated through the positions of climatic zones relative to positions of land masses and the resulting positions of ocean currents and temperature extremes. Thus, while an intermediate cyclothem might represent the 100-kyr period of a short eccentricity cycle, a major cyclothem may represent the positive feedback of two or possibly three of the short eccentricity cycles within a long eccentricity cycle. Moreover, we might expect that approximately 20 minor cycles controlled predominantly by precession might be nested within a 400-kyr grouping controlled predominantly by the long eccentricity cycle.

To approach the problem of determining the major controls over Pennsylvanian cyclicity, HeCKel (1986) initially made a series of assumptions about the ranges of durations of minor and intermediate cyclothems relative to major cyclothems and, using the poorly constrained estimates of radiometric dating at that time, showed that the frequency of the Pennsylvanian cyclothems had to fall within the general 20- to 400-kyr range of the orbital parameters. More recently, Heckel (2002b) assumed the accuracy of three radiometric age dates from the Appalachian succession that could be correlated approximately with the midcontinent succession where the record of cycles is much more complete. He grouped the Midcontinent cycles into presumed 400-kyr groupings that fit the three Appalachian dates, which placed the Carboniferous-Permian (C-P) boundary at $~ 290 \mathrm{Ma}$, where HARLAND et al. (1990) had estimated it. This resulted in 45 presumed 400-kyr groupings, 17 of which contained only minor and intermediate cyclothems, and 7 of which comprised only a single major cyclothem. Later, Heckel (2003) used the 296-Ma age of the C-P boundary estimated by MENNING et al. (2000) and regrouped the midcontinent cycles into 30 presumed 400-kyr groupings, only 5 of which contained no major cyclothems, and only two of which comprised a single major cyclothem. Then, Heckel (2004) assumed that the most recent radiometric dates (close to $299 \mathrm{Ma}$, see below) were more accurate for the C-P boundary and again regrouped the cycles into 26 presumed 400-kyr groupings, of which only 3 in the late Virgilian succession contain no major cyclothems, none comprise only a single major cyclothem, and more boundaries between groupings coincide with major lowstands. Subsequently, Heckel reduced the assumed duration of the middle and late Atokan (pre-Desmoinesian) section above the most accurate Appalachian date, and came 


\begin{tabular}{|c|c|c|c|c|}
\hline $\begin{array}{l}\text { Boundaries and } \\
\text { N. American stages / } \\
\text { [Global stages] }\end{array}$ & $\begin{array}{l}\text { Estimated dates } \\
\text { of GRADSTEIN } \\
\text { et al. (2004) }\end{array}$ & $\begin{array}{l}\text { Number of } 400-k y r \\
\text { cyclothem groupings } \\
\text { in stage }\end{array}$ & $\begin{array}{l}\text { Duration of stage, } \\
\text { based on number } \\
\text { of groupings }\end{array}$ & $\begin{array}{l}\text { Boundary calibration } \\
\text { (w. }{ }^{*} \text { precise } \\
\text { radiometric dates, Ma) }\end{array}$ \\
\hline $\begin{array}{l}\text { Carboniferous-Permian } \\
\text { boundary }\end{array}$ & $299.0 \mathrm{Ma}$ & & & $\begin{array}{l}298.6 \mathrm{Ma} \\
\text { (*298.4 } \pm 0.2, \mathrm{U}-\mathrm{Pb} \text {, } \\
\text { Urals) }\end{array}$ \\
\hline Virgilian [ Gzhelian] & & 10 & $4 \mathrm{myr}$ & \\
\hline $\begin{array}{l}\text { Missourian-Virgilian bdy } \\
\text { [ Kasim.-Gzhelian bdy] }\end{array}$ & 303.9 [K-G bdy] & & & $302.6 \mathrm{Ma}$ \\
\hline $\begin{array}{l}\text { Missourian } \\
{[\sim \text { Kasimovian, except }} \\
\text { base] }\end{array}$ & & $6[$ Kasim. = 8] & $\begin{array}{l}2.4 \mathrm{myr} \\
{[\text { Kasim. }=3.2]}\end{array}$ & \\
\hline $\begin{array}{l}\text { Desm.-Missourian bdy } \\
\text { [two } 400-\text { ka groupings } \\
\text { above Moscovian- } \\
\text { Kasimovian boundary] }\end{array}$ & 306.5 [M-K bdy] & & & $\begin{array}{l}305 \mathrm{Ma}[\mathrm{M}-\mathrm{K}=305.8] \\
\text { (*305.4 } \pm \mathbf{0 . 2}, \mathbf{U}-\mathbf{P b}, \\
\text { Urals) }\end{array}$ \\
\hline $\begin{array}{l}\text { Desmoinesian } \\
\text { [ upper Moscovian] }\end{array}$ & & 10 [u. Mosc. $=8]$ & $\begin{array}{l}4 \mathrm{myr} \\
{[\mathrm{u} . \text { Mosc. }=3.2]}\end{array}$ & \\
\hline Atokan-Desmoines. bdy & & & & $309 \mathrm{Ma}$ \\
\hline $\begin{array}{l}\text { mid+late Atokan } \\
\text { [ lower Moscovian] }\end{array}$ & & $\begin{array}{l}\text { (cycles not } \\
\text { identified) }\end{array}$ & (assumed 2 myr) & \\
\hline $\begin{array}{l}\text { early-mid Atokan bdy } \\
\text { [ Bashkirian-Mosc. bdy] }\end{array}$ & 311.7 [B-M bdy] & & & $\begin{array}{l}\text { (*311 } \pm 1.0, \mathrm{Ar} \\
\text { Appalach.) }\end{array}$ \\
\hline Total Desm.-Virgilian & & 26 & $10.4 \mathrm{myr}$ & \\
\hline
\end{tabular}

Fig. 15. Chart showing calibration of Middle-Late Pennsylvanian time scale by presumed 400-kyr cyclothem groupings, using estimated dates of GradsteIn et al. (2004), radiometric U-Pb zircon dates from correlated sections in southern Urals (Sснмiтz et al. 2005, V. Davydov, personal communication 2005), and an Appalachian Ar/Ar sanidine date of KunK \& RICE (1994). For discussion see text.

even closer $(298.6 \mathrm{Ma})$ to the more recent estimate $(299 \pm 0.8 \mathrm{Ma})$ of GradSTEIN et al. (2004) for the C-P boundary. The most recent $\mathrm{U}-\mathrm{Pb}$ zircon dates from the marine succession in the southern Urals (SCHMITZ et al. 2005, V. Davydov, personal communication 2005) place the C-P boundary at $298.4 \mathrm{Ma}$, and a tuff bed near the current top of the Moscovian at $305.4 \pm 0.2 \mathrm{Ma}$, which is about two presumed $400-\mathrm{kyr}$ groupings below the $305 \mathrm{Ma}$ cyclothem-calibrated date for the Desmoinesian-Missourian boundary (Fig. 15). This near-correspondence of two dates from the Urals with the current 400-kyr midcontinent cyclothem grouping shows that the calibration is becoming more accurate.

In the meantime, Algeo et al. (2004) identified 12 cycles of geochemical variation in TOC, total S, and total P (among others) within the undisturbed black facies of the Hushpuckney Shale of the major Swope cyclothem in Kansas, which contains only two other field-identified minor cycles. This would bring the total number of minor cycles recognized within this grouping to 14 , much closer to the expected content of 20 minor precession cycles that might be expected within a 400-kyr grouping, most of them hidden in 
the deep-water black shale facies on the lower shelf. Moreover, in the Appalachian Basin in eastern Ohio, Nadon \& Kelly (2004) discovered 5 minor cycles defined by minor sequence boundaries and palaeosols on outcrop within the Ames marine interval, which is correlated with the major Oread cyclothem in the Midcontinent. These high-shelf cycles appear to represent minor cycles that are presumably also hidden in the offshore condensed interval of the equivalent black Heebner Shale of the Oread cyclothem in the Midcontinent. These studies show that at least some of the "missed beats" of GolDHAMMER et al. (1990) can be identified at particular elevations on the shelf where facies were conspicuously affected by minor sea-level changes or where geochemical proxies recorded the changes within the same general facies.

\section{Potential and limitations of cyclostratigraphy}

As demonstrated in the three case studies above, cyclostratigraphy has a great potential to improve geologic time scales and to constrain palaeoclimatic processes that influenced the oceanic, biological, and sedimentary systems. However, the correct cyclostratigraphical interpretation of the sedimentary record may be hampered by several factors:

- Incompleteness of the stratigraphic record. Orbital cycles may not be recorded due to non-deposition or erosion. In addition, hiatuses may be associated with each individual cycle, particularly so in shallow platform and shallow lake settings.

- Distortion of the original signal. The orbital signal may be distorted on its passage from the top of the atmosphere to the depositional system to such a degree that it is difficult to identify or even cannot be recognized any more. This factor includes bioturbation and (early) diagenetic changes (FISCHER et al. 1991), although the latter may amplify the original signal as well. Changes in sedimentation rate related to amplitude of the forcing will also distort the original signal by creating additional peaks in the spectrum (HERBERT 1994). Generally, non-linear responses within the climate system to the initial forcing may create harmonics or combination tones with frequencies different from those of the primary Milankovitch cycles (RIall 2004).

- Weakness of the initial forcing. The orbital signal may initially be too weak or too attenuated to be recorded in the sedimentary system ("hidden cycles"). Typical examples are precession related cycles that were deposited at times of eccentricity minima when the precession amplitude is strongly reduced.

- "Autocyclic" processes. Local or regional processes that occur within the sedimentary system independent of orbital forcing may create similarly-looking facies patterns even on similar time scales (e. g., Strasser 1991, Westphal et al. 2000, Burgess 2001). Autocyclic processes do not only play a role in proximal sedimentary systems but include the behaviour of ice caps and oceans as well.

- Climatic cycles with periodicities that differ from the "classical" Milankovitch cycles may create similar repetitive changes recorded in the sedimentary system (e.g., "subMilankovitch cycles”, ZüHLKE 2004). Such an alternative interpretation, corroborated by $\mathrm{U} / \mathrm{Pb}$ datings, lies at the base of the so-called "Latemar controversy" about the origin of shallowing-upward carbonate sequences in the Triassic Latemar platform (e. g., Hinnov \& Goldhammer 1991, Brack et al. 1996). 
- Correlation between different regions and sedimentary environments. The correlation of orbitally induced sedimentary cycles between different depositional environments and from one palaeoclimatic zone to another may be difficult because each environment or zone records the orbital signal in a different way. Nevertheless, such correlations have been established convincingly for Miocene to Pleistocene times (e.g., Hooghiemstra et al. 1993, van Vugt et al. 1998). Magnetostratigraphy often plays an important role in such attempts by providing independent lines of correlation.

- Astronomical tuning. A disadvantage of astronomical tuning to establish palaeoclimatic time series for time series analysis is that frequencies of the target curve are automatically introduced in the time series (e. g., SHACKLETON et al. 1995). Nevertheless, tuning remains a very powerful tool to study phase relations between the initial forcing and its recording in the sediments.

Despite these caveats, the cyclostratigraphic method has great potential. Major advantages and applications are:

- Optimal time resolution. Cyclostratigraphy, especially in combination with other stratigraphic disciplines, can be used to achieve the highest possible time resolution $(20 \mathrm{kyr})$ for pre-Quaternary studies where the precision of other dating methods is low. For example, high-resolution integrated stratigraphic (including cyclostratigraphic) correlations show that Messinian evaporites started at exactly the same time in the western and eastern Mediterranean basin (5.96 Ma; KrIJGSMAN et al. 1999). Similar detailed correlations were used to demonstrate that the restoration of an open marine connection between the Mediterranean and Atlantic and associated basal Pliocene flooding of the Mediterranean, following the Messinian salinity crisis, is unrelated to any major deglaciation and, hence, to glacio-eustatic sea-level rise (VAN DER LAAN et al. 2006). Once the duration of a sedimentary cycle is defined, a very detailed analysis of sedimentological, palaeoecological, or geochemical changes can be performed, and rates of these changes can be evaluated (e.g., Strasser \& Samankassou 2003, Amodio 2006, Vincent et al. 2006).

- Accurate astronomical time scales. Cyclostratigraphy permits to establish an anchored astronomical time scale tied to the Present. Astronomical tuning now directly underlies the standard time scale for the Neogene (NAish et al. 1998, Lourens et al. 2004), which is incorporated in the Geological Time Scale 2004 (Gradstein et al. 2004). Remarkably enough, ages for the Pliocene-Pleistocene part of the new Neogene time scale differ by less than $1 \mathrm{kyr}$ from the tuned time scale of Lourens et al. (1996). This astronomical time scale is now being extended into the Mesozoic mainly on the basis of extra-Mediterranean (I)ODP successions (e. g., PäLike et al. 2001, Wade \& PÄLIKE 2004), although land-based marine sections in, e.g., Italy and Spain provide a fully acceptable alternative (Dinaresturrell et al. 2003). Deeper in the geologic past, "floating" astronomical time scales have been established which provide the astronomical duration (but not the age) of an interval. In this way, a high time resolution is obtained in an interval that displays orbital cyclicity, although its radiometric age remains subject to the error margins of the dating methods (e. g., STRAsSER \& HillGÄrtner 1998, Kent \& Olsen 1999, examples in D’Argenio et al. 2004). 
- Improved definition of Global Stratotype Sections and Points (GSSPs). An extra requirement for the establishment of GSSPs (REMANE et al. 1996) was added for the definition of Neogene stage boundaries, namely that they are defined in astronomically tuned deep marine sections. The advantage of the Mediterranean is that all Late Neogene stage boundaries as defined by their GSSPs are now defined in tuned sections; hence these GSSPs are directly linked to the standard geological time scale. Most of these sections are demonstrably continuous and may be designated as unit-stratotypes for global stages in the future. Thereby, the 400-kyr cycle may specifically be defined as formal chronozone, i. e. as a non-hierarchical chronostratigraphic unit of lower rank (Hilgen et al. 2005).

- Astronomical climate forcing. Cyclostratigraphic analysis helps to understand how the climate system responded to astronomical forcing under different palaeogeographic settings in the past. Changes in ocean circulation can be monitored for example to see if a high-latitude obliquity signal is recorded in low latitude basins where otherwise the precession cycle predominates (Lourens et al. 1992, Giraud et al. 1995). The results of these studies can be compared to the outcome of climate modelling experiments of orbital extremes and may be extrapolated to help understand and predict future climate change. The latter is especially important because the primary cycles may give rise to much shorter cycles through non-linear interactions in the climate system (RIALL 2004).

- Link to sequence stratigraphy. Of particular interest is the connection between the long-period astronomical cycles of eccentricity ( 0.4 and 2.4 myr) and obliquity (1.2 myr) and third-order sequences in sequence stratigraphy (e. g., GARcía et al. 1996, Strasser et al. 2000, Gale et al. 2002, Matthews \& Frohlich 2002). This combination has great potential to improve the regional and inter-regional correlation of sequences and may contribute to the debate about the global synchrony of eustatic sea-level changes (Miall \& Miall 2001). There is also a potential to refine the time frame of sequence-stratigraphic continent-to-basin correlations by cyclostratigraphic analysis of the intervals between sequence boundaries and maximum-flooding surfaces (e. g., Montañez \& Osleger 1993, Pasquier \& Strasser 1997).

- Intercalibration with radiometric dating methods. Comparison and intercalibration with independent radio-isotopic dating methods is fundamentally important. For example, new radiometric age dating recently challenged the up to then widely accepted cyclostratigraphical interpretation of the Middle Triassic Latemar platform in Italy (e.g., Goldhammer et al. 1987, Hinnov \& Goldhammer 1991, Brack et al. 1996, Egenhoff et al. 1999, ZüHLke 2004). At the Tortonian GSSP at Monte dei Corvi (Italy), however, new ${ }^{40} \mathrm{Ar} /{ }^{39} \mathrm{Ar}$ ages essentially confirm the cyclostratigraphic dating (Kuiper et al. 2005). Nevertheless, a detailed comparison of the astronomical and ${ }^{40} \mathrm{Ar} /{ }^{39} \mathrm{Ar}$ ages reveals a rather consistent offset of $\sim 0.8 \%$, the astronomical ages being older (KUIPER 2003). This study provides an astronomical age for mineral dating standards and opens the possibility for the introduction of an astronomically dated standard in ${ }^{40} \mathrm{Ar} /{ }^{39} \mathrm{Ar}$ dating. An accurate and precise intercalibration is especially important by providing tight constraints for the astronomical tuning when it is extended into the Mesozoic. 
- Link to biostratigraphy and biochronology. The integrated stratigraphic approach, including cyclostratigraphy and astronomical tuning, allows us to evaluate for the first time the synchronous or diachronous nature of biohorizons across and between basins in great detail (e. g., Hilgen et al. 2000, Lirer \& Iaccarino 2005, Heckel et al. 2005), which of course has important implications for biostratigraphic correlation.

\section{Recommendations for cyclostratigraphic nomenclature}

Stratigraphic nomenclature should be precise yet practical in order to be useful to the scientific community. Unfortunately, a multitude of terms exists in the literature, which describe repetitive patterns in the sedimentary record: cycles, cyclothems, rhythms, periodites, sequences, parasequences, etc. Elementary or basic units may be hierarchically stacked and grouped into bundles, clusters, or sequences of different orders. Some studies use the above terms in a purely descriptive way, while others imply a time-significance and thus involve cyclostratigraphy. Concerning cyclostratigraphy, HiLGEN et al. (2004) proposed the following definitions to clarify the cyclostratigraphic concept and define its terminology:

Cyclostratigraphy. The subdiscipline of stratigraphy that deals with the identification, characterization, correlation, and interpretation of cyclic (periodic or quasi-periodic) variations in the stratigraphic record and, in particular, with their application in geochronology by improving the accuracy and resolution of time-stratigraphic frameworks.

Sedimentary cycle (as used in cyclostratigraphy). One succession of lithofacies that repeats itself many times in the sedimentary record and that is, or is inferred to be, causally linked to an oscillating system and, as a consequence, is (nearly) periodic and has time significance.

Astronomical tuning. The correlation or tuning of sedimentary cycles or cyclic variations in climate proxy records to astronomical target curves of precession, obliquity and/or eccentricity, or to related insolation curves.

Astronomical time scale (ATS). A geological time scale with absolute ages derived from the calibration of sedimentary cycles and other cyclic variations in sedimentary successions to astronomical time series.

Astrocycle. While "cyclostratigraphy" and "astronomical time scale" are straightforward definitions, the term "sedimentary cycle" is not an ideal choice. This term is used in many different ways in sedimentology and sequence stratigraphy and is first of all descriptive. The time significance of a sedimentary cycle and, consequently, its use for cyclostratigraphy and astrochronology can only be determined after detailed analyses. For example, an elementary cycle recognized in one system or in one stratigraphic interval may correspond to the $20-k y r$ precession cycle, while an elementary cycle elsewhere represents the 100-kyr eccentricity cycle because the facies contrasts are not strong enough to resolve cycles with a shorter period. As an alternative, we propose "astrocycle" as an unequivocal term that exclusively designates orbital-induced sedimentary or geochemical cycles.

Cyclothem. This term was specifically introduced by WANLEss \& Weller (1932, p. 1003) “... to designate a series of beds deposited during a single sedimentary cycle of 
the type that prevailed during the Pennsylvanian period.” Because the authors recognized this unit as a product of marine transgression and regression with erosional disconformities at the lower and upper boundaries, and because WANLess \& SHEPARD (1936) interpreted these depositional units as resulting from glacial eustasy, this term should be applied mainly to the shelf manifestation of a transgressive-regressive unit or stratigraphic sequence that resulted from glacial eustasy (see also glossary).

\section{Conclusions}

Cyclostratigraphy is a stratigraphic method that analyses the sedimentary record and identifies patterns of repetitive changes, which above all can be attributed to the orbital parameters of the Earth. If it can be demonstrated - through independently dated tie points and time series analysis - that the observed changes are indeed related to the orbital cycles, then a time frame can be established that has a resolution of 20 to $100 \mathrm{kyr}$. In preQuaternary stratigraphic series, this is much more precise than the resolution achieved by other geochronological methods. Such astronomical time scales can then be used to improve the definition of GSSPs, to refine stratigraphic correlations, and to estimate rates of palaeoclimatic, palaeoceanographic, sedimentary, biological, and diagenetic processes. However, because the translation of orbital cycles into the sedimentary record passes through various and complex feed-back loops, it cannot be expected that cyclostratigraphical analysis is an easy task. It is especially important to have a good understanding of the depositional environment where the cyclical record formed.

In order to clearly distinguish between sedimentary cycles that are purely descriptive and those that can be used for astrochronology, we propose the term "astrocycle" for cycles with an established time significance.

Acknowledgements. We thank Maria Bianca Cita (chairwoman of the ISSC) for encouraging us to write this contribution. We also thank Albert Brakel, Ki-Hong Chang, Roger Cooper, Wayne Cowley, Geza Csaszar, Michael Dermitzakis, Ashton Embry, Stan Finney, Yuri Gladenkov, Felix Gradstein, Yuri Karogodin, Manfred Menning, Andrew Miall, Brian Pratt, Yokichi Takayanagi, Walther Schwarzacher, Bruce Waterhouse, George Williams, Henk Winter, and Jan Zalasiewicz for their constructive comments. AS acknowledges the financial support by the Swiss National Science Foundation (project 20-67736.02).

\section{References}

Abdul Aziz, H., F.J.Hilgen, W. Krijgsman \& J. P. Calvo (2003): An astronomical polarity time scale for the late middle Miocene based on cyclic continental sequences. - J. Geophys. Res. 108(B3): 2159, doi:10.10129/2002JB001818, St. Louis.

Abels, H., F.J.Hilgen, W.Krijgsman, R.Kruk, I. Raffi, E.Turco \& W.J.Zachariasse (in press): Long-period orbital control on middle Miocene global cooling: Integrated stratigraphy and astronomical tuning of the Ras il Pellegrin section on Malta. - Paleoceanography, Washington.

Adhémar, J. A. (1842): Révolutions de la mer. - Private edition, Paris. 
Algeo, T.J., L.Schwark \& J.C. Hower (2004): High-resolution geochemistry and sequence stratigraphy of the Hushpuckney Shale (Swope Formation, eastern Kansas): Implications for climato-environmental dynamics of the Late Pennsylvanian Midcontinent Sea. - Chem. Geol. 206: 259-288, Amsterdam.

АмоDIO, S. (2006): Foraminifera diversity changes and paleoenvironmental analysis: the Lower Cretaceous shallow-water carbonates of San Lorenzello, Campanian Apennines, southern Italy. - Facies 52: 53-67, Erlangen.

Berger, A.L. (1977): Long-term variations of the Earth's orbital elements. - Celestial Mechanics 15: $53-74$.

Berger, A. L. (1978): Long-term variations of caloric insolation resulting from the Earth's orbital elements. - Quaternary Research 9: 139-167, Washington.

Berger, A., M.F.Loutre \& V.Dehant (1989): Astronomical frequencies for pre-Quaternary palaeoclimate studies. - Terra Nova 1: 474-479, Oxford.

Berger, A., M.F. Loutre \& J. Laskar (1992): Stability of the astronomical frequencies over the Earth's history for paleoclimate studies. - Science 255: 560-566, Washington.

Berggren, W.A., D. V.Kent, M.-P. Aubry \& J.Hardenbol (eds.) (1995): Geochronology, time scales, and global stratigraphic correlation. - SEPM Special Publication 54: 386 p., Tulsa.

Brack, P., R. Mundil, F. Oberli, M. Meier \& H. Rieber (1996): Biostratigraphic and radiometric age data question the Milankovitch characteristics of the Latemar cycles (Southern Alps, Italy). Geology 24: 371-375, Boulder.

BraDley, W.H. (1929): The varves and climate of the Green River epoch. - U.S. Geol. Surv. Prof. Paper 158: 87-110.

Brescia, M., B. D’Argenio, V. Ferreri, N. Pelosi, S. Rampone \& R. Tagliaferri (1996): Neural net aided detection of astronomical periodicities in geologic records. - Earth Planet. Sci. Lett. 139: 33-45, Amsterdam.

BuRGESs, P.M. (2001): Modeling carbonate sequence development without relative sea-level oscillations. - Geolgy 29: 1127-1130, Boulder.

Clavel, B., J. Charollais, R. Busnardo \& G. Le Hegarat (1986): Précisions stratigraphiques sur le Crétacé inférieur basal du Jura méridional: Eclogae Geol. Helv. 79: 319-341, Basel.

Croll, J. (1864): On the physical cause of the change of the climate during geological epochs. - Phil. Mag. 28: $121-137$.

Croll, J. (1875): Climate and time in their geological relations. - Appleton, New York.

D’Argenio, B., A. G. Fischer, I. Premoli Silva, H. Weissert \& V. Ferreri (eds.) (2004): Cyclostratigraphy: approaches and case histories. - SEPM Spec. Publ. 81: 311 p., Tulsa.

De Boer, P. L. \& D. G. Smith (1994): Orbital forcing and cyclic sequences. - IAS Spec. Publ. 19: 559 p., Oxford.

De Geer, G. (1912): A geochronology of the last 12,000 years. - 11th Int. Geol. Congress, Stockholm, 1910, Proceedings 1: 241-253.

Dercourt, J., M. Gaetani, B. Vrielynck, E. Barrier, B. Bijuduval, M. F. Brunet, J. P. Cadet, S. Crasquin \& M.SAndulescu (eds.) (2000): Atlas Peri-Tethys - Palaeogeographical maps, Paris.

Détraz, H. \& P.-O.Mojon (1989): Evolution paléogéographique de la marge jurassienne de la Téthys du Tithonique-Portlandien au Valanginien: corrélations biostratigraphique et séquentielle des faciès marins à continentaux. - Eclogae Geol. Helv. 82: 37-112, Basel.

Dinares-Turrell, J., J. I. Baceta, V. Pujalte, X. Orue-Etxebarria, G. Bernaola \& S. Lorito (2003): Untangling the Palaeocene climatic rhythm: an astronomically calibrated Early Palaeocene magnetostratigraphy and biostratigraphy at Zumaia (Basque basin, northern Spain). - Earth Planet. Sci. Lett. 216: 483-500, Amsterdam.

Egenhoff, S., A. PeterhäNSEL, T. BechstäDt, R. Zühlke \& J. Grötsch (1999): Facies architecture of an isolated carbonate platform: tracing the cycles of the Latemar (Middle Triassic, northern Italy). - Sedimentology 46: 893-912, Oxford. 
Einsele, G. \& W. Ricken (1991): Limestone-marl alternation - an overview. In: Einsele, G., W. Ricken \& A. Seilacher (eds.): Cycles and events in stratigraphy. - Springer-Verlag: 23-47, Heidelberg.

Einsele, G., W. Ricken \& A. Seilacher (eds.) (1991): Cycles and events in stratigraphy. - SpringerVerlag: 955 p., Heidelberg.

Emiliani, C. (1955): Pleistocene temperatures. - J. Geol. 63: 538-578, Chicago.

Fischer, A. G. (1964): Lofer cyclothems of the Alpine Trias. - Kansas Geol. Surv. Bull. 169: 107-148.

Fischer, A. G., B. D’Argenio, I. Premoli Silva, H. Weissert \& V. Ferreri (2004): Cyclostratigraphic approach to Earth's history: an introduction. - SEPM Spec. Publ. 81: 5-13, Tulsa.

Fischer, A. G., P. L. De Boer \& I. Premoli Silva (1988): Cyclostratigraphy. In: Beaudoin, B. \& R. N. Ginsburg (eds.): Global Sedimentary Geology Program: Cretaceous Resources, Events, and Rhythms. - NATO ASI Series, Kluwer, 139-172, Dordrecht.

Fischer, A.G., T.D. Herbert, G. Napoleone, I. Premoli Silva \& M. Ripepe (1991): Albian pelagic rhythms (Piobbico core). - J. Sed. Petrol. 61: 1164-1172, Tulsa.

Foucault, A. \& F. Melières (2000): Paleoclimatic cyclicity in central Mediterranean Pliocene sediments: the mineralogic signal. - Palaeogeogr., Palaeoclimatol., Palaeoecol. 158: 311-323, Amsterdam.

Frakes, L. A., J. E. Francis \& J. I. SykTus (1992): Climate modes of the Phanerozoic. - Cambridge Univ. Press, 274 p., Cambridge.

Gale, A.S., J. Hardenbol, B. Hathway, W.J. Kennedy, J. R. Young \& V. Phansalkar (2002): Gobal correlation of Cenomanian (Upper Cretaceous) sequences: evidence for Milankovitch control on sea level. - Geology 30: 291-294, Boulder.

García, A., M.Segura \& J.F. García-Hidalgo (1996): Sequences, cycles and hiatuses in the Upper Albian-Cenomanian of the Iberian Ranges (Spain): a cyclostratigraphic approach. - Sed. Geol. 103: 175-200, Amsterdam.

GilberT, G. K. (1895): Sedimentary measurement of Cretaceous time. - J. Geol. 3: 121-127, Chicago.

Giraud, F., L. Beaufort \& P. Cotillon (1995): Periodicities of carbonate cycles in the Valanginian of the Vocontian Trough: a strong obliquity control. In: House, M. R. \& A.S. Gale (eds.): Orbital forcing time-scales and cyclostratigraphy. - Geol. Soc. Spec. Publ. 85: 143-164, London.

Goldhammer, R. K., P. A. Dunn \& L. A. Hardie (1987): High-frequency glacio-eustatic oscillations with Milankovitch characteristics recorded in northern Italy. - Amer. J. Science 287: 853892, New Haven.

Goldhammer, R. K., P. A. Dunn \& L. A. Hardie (1990): Depositional cycles, composite sea-level changes, cycle stacking patterns, and the hierarchy of stratigraphic forcing: examples from Alpine Triassic platform carbonates. - GSA Bull. 102: 535-562, Boulder.

Gornitz, V., S. LebedefF \& J. Hansen (1982): Global sea-level trend in the past century. - Science 215: 1611-1614, Washington.

Gradstein, F.M., F. P. Agterberg, J. G. Ogg, J. Hardenbol, P. van Veen, J. Thierry \& Z. Huang (1995): A Triassic, Jurassic and Cretaceous time scale. In: Berggren, W. A., D. V. Kent, M. P. Aubry \& J. Hardenbol (eds.): Geochronology, time scales and global stratigraphic correlation. - SEPM Spec. Publ. 54: 95-126, Tulsa.

Gradstein, F. M., J. G. Ogg \& A. G. Smith (eds.) (2004): A geologic time scale 2004. - Cambridge Univ. Press, 589 p., Cambridge.

Hays, J. D., J. Imbrie \& N. J. Shackleton (1976): Variations in the Earth's orbit: pacemakers of the ice ages. - Science 194: 1121-1132, Washington.

Hardenbol, J., J. Thierry, M.B. Farley, T. Jacquin, P.-C. De Graciansky \& P. R. Vail (1998): Charts. In: De Graciansky, P.-C., J. Hardenbol, T. Jacquin \& P. R. Vail (eds.): Mesozoic and Cenozoic sequence stratigraphy of European basins. - SEPM Spec. Publ. 60, Tulsa.

Harland, W.B., R. L. Armstrong, A. V. Cox, L. E. Craig, A. G. Smith \& D. G. Smith (1990): A geologic time scale 1989. - Cambridge University Press, 263 p., Cambridge.

Heckel, P. H. (1984): Changing concepts of Midcontinent Pennsylvanian cyclothems, North America. In: Belt, E.S. \& R. W. Macqueen (eds.): Part 3: Sedimentology and geochemistry. - 9ième 
Congrès Int. Stratigraphie et Géologie du Carbonifère, Washington and Champaign-Urbana 1979, Compte Rendu 3. Southern Illinois University Press: 535-553, Carbondale.

Heckel, P. H. (1986): Sea-level curve for Pennsylvanian eustatic marine transgressive-regressive depositional cycles along midcontinent outcrop belt, North America. - Geology 14: 330-334, Boulder. Heckel, P. H. (1994): Evaluation of evidence for glacial-eustatic control over marine Pennsylvanian cyclothems in North America and consideration of possible tectonic effects. In: DENNISON, J. M. \& F. R. ETTENSOHN (eds.): Tectonic and eustatic controls on sedimentary cycles. - SEPM Concepts in Sedimentology and Paleontology 4: 65-87, Tulsa.

Heckel, P. H. (2002a): Overview of Pennsylvanian cyclothems in Midcontinent North America and brief summary of those elsewhere in the world. - Canadian Soc. Petrol. Geol. Mem. 19: 79-98.

Heckel, P.H. (2002b): Observations and constraints on radiometric dating of the Pennsylvanian succession in North America and its correlation with dates from Europe. - Newsletter on Carboniferous Stratigraphy 20: 10-14.

Heckel, P. H. (2003): Updated cyclothem constraints on radiometric dating of the Pennsylvanian succession in North America and its correlation with dates from Europe. - Newsletter on Carboniferous Stratigraphy 21: 12-20.

Heckel, P.H.(2004): Updated cyclothem grouping chart and observations on the grouping of Pennsylvanian cyclothems in Midcontinent North America. - Newsletter on Carboniferous Stratigraphy 22: $18-22$.

Heckel, P.H., and 13 others (2005): Cyclothem [sequence-stratigraphic] correlation and biostratigraphy across the Moscovian-Kasimovian and Kasimovian-Gzhelian stage boundaries (Upper Pennsylvanian Series) in North America and Eurasia. - Newsletter on Carboniferous Stratigraphy 23: 36-44.

Hedberg, H. D. (ed.) (1976): International Stratigraphic Guide - a guide to stratigraphic classification, terminology, and procedure. - Wiley, 200 p., New York.

Herbert, T. D. (1994): Reading orbital cycles distorted by sedimentation: models and examples. IAS Spec. Publ. 19: 483-507, Oxford.

Hilgen, F.J. (1991): Astronomical calibration of Gauss to Matuyama sapropels in the Mediterranean and implication for the GPTS. - Earth Plan. Sci. Lett. 104: 226-244, Amsterdam.

Hilgen, F.J., H. Brinkhuis \& W. J.Zachariasse (2006): Unit stratotypes for global stages. The Neogene perspective. - Earth Sci. Reviews 74: 113-125, Amsterdam.

Hilgen, F. J., L.J. Lourens, A. L. Berger \& M. F. Loutre (1993): Evaluation of the astronomical calibrated time scale for the late Pliocene and earliest Pleistocene. - Paleoceanography 8: 549565, Washington.

Hilgen, F. J., W. Krijgsman, C. G. Langereis, L. J. Lourens, A. Santarelli \& W. J. Zachariasse (1995): Extending the astronomical time scale into the Miocene. - Earth Planet. Sci. Lett. 136: 495-510, Amsterdam.

Hilgen, F.J., W. Krijgsman, I. Raffi, E. Turco \& W.J. Zachariasse (2000): Integrated stratigraphy and astronomical calibration of the Serravallian/Tortonian boundary section at Monte Giblisciemi, Sicily. - Mar. Micropaleontol. 38: 181-211, Amsterdam.

Hilgen, F. J., H. Abdul Aziz, W. Krijgsman, I. Raffi \& E. Turco (2003): Integrated stratigraphy and astronomical tuning of the Serravallian and lower Tortonian at Monte dei Corvi (Middle-Upper Miocene, northern Italy). - Palaeogeogr. Palaeoclimatol. Palaeoecol. 199: 229-264, Amsterdam.

Hilgen, F. J., W.Schwarzacher \& A. STrasser (2004): Concepts and definitions in cyclostratigraphy (second report of the cyclostratigraphy working group). - SEPM. Spec. Publ. 81: 303-305, Tulsa.

Hillgärtner, H. (1998): Discontinuity surfaces on a shallow-marine carbonate platform (Berriasian - Valanginian, France and Switzerland). - J. Sed. Res. 68: 1093-1108, Tulsa.

Hillgärtner, H. (1999): The evolution of the French Jura platform during the Late Berriasian to Early Valanginian: controlling factors and timing. - GeoFocus 1: 203 p., Fribourg.

Hinnov, L. A. (2000): New perspectives on orbitally forced stratigraphy. - Ann. Rev. Earth Planet. Sci. 28: 419-475, Amsterdam. 
Hinnov, L. A. \& R. K. Goldhammer (1991): Spectral analysis of the Middle Triassic Latemar limestone. - J. Sed. Petrol., 61: 1173-1193, Tulsa.

Hooghiemstra, H., J. L. Melice, A. Berger \& N.J. Shackleton (1993): Frequency spectra and palaeoclimatic variability of the high-resolution 30-1450 kyr Funza-1 pollen record (Eastern Cordillera, Columbia). - Quat. Sci. Rev. 12: 141-156, Amsterdam.

House, M. R. (1995): Orbital forcing time-scales: an introduction. - Geol. Soc. Spec. Publ. 85: 1 18, London.

House, M. R. \& A.S. Gale (1995): Orbital forcing time-scales and cyclostratigraphy. - Geol. Soc. Spec. Publ. 85: 210 p., London.

Jacobs, D. K. \& D. L. SAHAGian (1993): Climate-induced fluctuations in sea level during non-glacial times. - Nature 361: 710-712, London.

Kent, D. V. \& P. E. Olsen (1999): Astronomically tuned geomagnetic polarity time scale for the Late Triassic. - J. Geophys. Res. 104: 12831-12841.

Krijgsman, W., S. Gaboardi, F. J. Hilgen, S. Iaccarino, E. de Kaenel \& E. van der LaAn (2004): Revised astrochronology for the Ain el Beida section (Atlantic Morocco): No glacio-eustatic control for the onset of the Messinian Salinity Crisis. Stratigraphy 1: 87-101.

Krijgsman, W., F.J.Hilgen, I. Raffi, F. J. Sierro \& D. S. Wilson (1999): Chronology, causes and progression of the Messinian salinity crisis. - Nature 400: 652-655, London.

KuIPER, K. F. (2003): Direct intercalibration of radio-isotopic and astronomical time in the Mediterranean Neogene. - Geol. Ultraiectina 135: 223 pp. (http://www.geo.uu.nl/Research/Paleomagnetism/people/Klaudia/Thesis_Kuiper.pdf).

Kuiper, K. F., F.J.HILGEN, J.STEENBRINK \& J. R. WiJbRAns (2004): ${ }^{40} \mathrm{Ar} /{ }^{39} \mathrm{Ar}$ ages of tephras intercalated in astronomical tuned Neogene sedimentary sequences in the eastern Mediterranean. Earth Planet. Sci. Lett. 222: 583-597, Amsterdam.

KuIPER, K. F., J.R. Wijbrans \& F. J. Hilgen (2005): Radioisotopic dating of the Tortonian Global Stratotype Section and Point: implications for intercalibration of ${ }^{40} \mathrm{Ar} /{ }^{39} \mathrm{Ar}$ and astronomical dating methods. - Terra Nova 17: 385-398, Oxford.

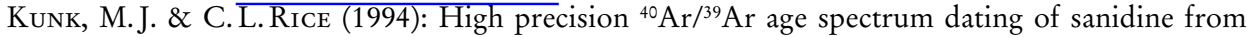
the Middle Pennsylvanian Fire Clay tonstein of the Appalachian Basin. - GSA Special Paper 294: 105-113, Boulder.

LASKAR, J. (1989): A numerical experiment on the chaotic behaviour of the solar system. - Nature 338: 237-238, London.

LASKAR, J. (1999): The limits of the Earth orbital calculations for geological time-scale use. - Royal Soc. London Phil. Trans. Ser. A 357: 1735-1759, London.

Laskar, J., P. Robutel, F. Joutel, M. Gastineau, A. C. M. Correia \& B. Levrard (2004): A long term numerical solution for insolation quantities of the Earth. - Astron. Astrophys. doi: 10.1051/ 0004-6361:20041335.

Le Hegarat, G. (1971): Le Berriasien du Sud-Est de la France. - Doc. Lab. Géol. Faculté des Sciences 43: 576 p., Lyon.

LiReR, F. \& S. IACCARINO (2005): Integrated stratigraphy (cyclostratigraphy and biochronology) of late Middle Miocene deposits in the Mediterranean area and comparison with the North and Equatorial Atlantic Oceans: synthesis of major results. - Terra Nova 17: 338-349, Oxford.

Lorius, C., J. Jouzel \& D. Raynaud (1993): Glacials-interglacials in Vostok: climate and greenhouse gases. - Global Planet. Change 7: 131-143, Amsterdam.

Lourens, L.J., F. J.Hilgen, L. Gudjonsson \& W.J.Zachariasse (1992): Late Pliocene - early Pleistocene astronomically forced surface water productivity and temperature variations in the Mediterranean. - Mar. Micropaleontol. 19: 49-78, Amsterdam.

Lourens, L.J., A. Antonarakou, F.J.Hilgen, A.A.M.Van Hoof, C.Vergnaud-Grazzini \& W.J.Zachariasse (1996): Evaluation of the Plio-Pleistocene astronomical timescale. - Paleocenography 11: 391-413, Washington. 
Lourens, L. J., R. Wehausen \& H. J. Brumsack (2001): Geological constraints on tidal dissipation and dynamical ellipticity of the Earth over the past 3 million years. - Nature 409: 1029-1033.

Lourens, L., F. Hilgen, N. J. Shackleton, J. Laskar \& D. Wilson (2004): The Neogene period. In: Gradstein, F. M., J. G. Ogg \& A. G. Sмith (eds.): A geologic time scale 2004. - Cambridge Univ. Press: 409-440, Cambridge.

Matthews, M.D. \& M.A. Perlmutter (1994): Global cyclostratigraphy: an application to the Eocene Green River Basin. - IAS Spec. Publ. 19: 459-481, Oxford.

Matthews, R. K. \& C. Frohlich (2002): Maxiumum flooding surfaces and sequence boundaries: comparisons between observations and orbital forcing in the Cretaceous and Jurassic (65$190 \mathrm{Ma})$. - GeoArabia 7: 503-538, Bahrain.

Menning, M., D. Weyer, G. Drozdzewski, H. W.J. van Amerom \& I. Wendt (2000): A Carboniferous Time Scale 2000: discussion and use of geological parameters as time indicators from Central and Western Europe. - Geol. Jb. Hannover A 156: 3-44, Hannover.

Miall, A. D. \& C. E. Miall (2001): Sequence stratigrapy as a scientific enterprise: the evolution and persistence of conflicting paradigms. - Earth-Sci. Reviews 54, 321-348, Amsterdam.

Milankovitch, M. (1920): Théorie mathématique des phénomènes thermiques produits par la radiation solaire. - Acad. Yougoslave Sci. Arts, Zagreb.

Milankovitch, M. (1941): Kanon der Erdbestrahlung und seine Anwendung auf das Eiszeitenproblem. - Acad. Roy. Serbe 133: 633 p., Belgrade.

Mommersteeg, H. J. P. M., M.-F. Loutre, R. Young, T. A. Wijmstra \& H. Hooghiemstra (1995): Orbital forced frequencies in the 975000 year pollen record from Tenagi Philippon (Greece). Climate Dynamics 11: 4-24, Berlin.

MoNTAÑeZ, I. P. \& D. A. Osleger (1993): Parasequence stacking patterns, third-order accommodation events, and sequence stratigraphy of Middle to Upper Cambrian platform carbonates, Bonanza King Formation, southern Great Basin. - AAPG Mem. 57: 305-326, Tulsa.

Myers, P. G. (2002): Flux-forced simulations of the paleocirculation of the Mediterranean. Paleoceanography 17: $1-7$, Washington.

Nadon, G. C. \& R. R. Kelly (2004): The constraints of glacial-eustasy and low accommodation on sequence stratigraphic interpretations of Pennsylvanian strata, Conemaugh Group, Appalachian basin, USA. In: Pashin, J. C. \& R. A. Gastaldo (eds.): Sequence stratigraphy, paleoclimate, and tectonics of coal-bearing strata. - AAPG Studies in Geology 51: 29-44, Tulsa.

Naish, T. R., S. T. Авbott, B. V. Alloway, A. G. Beu, R. M. Carter, A. R. Edwards, T. D. Journeaux, P. J. J. Kamp, B. J. Pillans, G. Saul \& K. J. Woolfe (1998): Astronomical calibration of a southern hemisphere Plio-Pleistocene reference section, Wanganui Basin, New Zealand. - Quat. Sci. Rev. 17: 695-710, Amsterdam.

OsLEGER, D. (1991): Subtidal carbonate cycles: implications for allocyclic vs. autocyclic controls. Geology 19: 917-920, Boulder.

Pälike, H., N. J. Shackleton \& U. Röhl (2001). Astronomical forcing in Late Eocene marine sediments. - Earth Planet. Sci. Lett. 193: 589-602, Amsterdam.

PAsquier, J.-B. (1995): Sédimentologie, stratigraphie séquentielle et cyclostratigraphie de la marge nord-thétysienne au Berriasien en Suisse occidentale (Jura, Helvétique et Ultrahelvétique; comparaison avec les séries de bassin des domaines vocontien et subbriançonnais). - Unpubl. PhD Thesis, Univ. Fribourg: 274 p.

Pasquier, J.-B. \& A. Strasser (1997): Platform-to-basin correlation by high-resolution sequence stratigraphy and cyclostratigraphy (Berriasian, Switzerland and France). - Sedimentology 44: 1071-1092, Oxford.

PepPers, R.A. (1996): Palynological correlation of major Pennsylvanian (Middle and Upper Carboniferous) chronostratigraphic boundaries in the Illinois and other coal basins. - GSA Mem. 188: 111 p., Boulder.

Pisias, N. G. \& J. Imbrie (1986): Orbital geometry, $\mathrm{CO}_{2}$, and Pleistocene climate. - Oceanus 29/4: $43-49$. 
Pittet, B. \& E. Mattioli (2002): The carbonate signal and calcareous nannofossil distribution in an Upper Jurassic section (Balingen-Tieringen, Late Oxfordian, southern Germany). - Palaeogeogr., Palaeoclimatol., Palaeoecol. 179: 71-96, Amsterdam.

PitTET, B. \& A.STRASSER (1998): Depositional sequences in deep-shelf environments formed through carbonate-mud export from the shallow platform (Late Oxfordian, German Swabian Alb and eastern Swiss Jura. - Eclogae Geol. Helv. 91: 149-169, Basel.

Preto, N., L.A.Hinnov, V.De Zanche, P. Mietto \& L.A. Hardie (2004): The Milankovitch interpretation of the Latemar platform cycles (Dolomites, Italy): implications for geochronology, biostratigraphy, and Middle Triassic carbonate accumulation. - SEPM Spec. Publ. 81: 167182, Tulsa.

Read, J. F. \& R. K. Goldhammer (1988): Use of Fischer plots to define third-order sea-level curves in Ordovician peritidal cyclic carbonates, Appalachians. - Geology 16: 895-899, Boulder.

READ, J.F. (1995): Overview of carbonate platform sequences, cycle stratigraphy and reservoirs in greenhouse and ice-house worlds. - SEPM Short Course 35: 1-102, Tulsa.

Remane, J., M. G. Bassett, J. W. Cowie, K. H. Gohrbandt, H. R. Lane, O. Michelsen \& W. NaiWEN (1996): Revised guidelines for the establishment of global chronostratigraphic standards by the International Commission on Stratigraphy (ICS). - Episodes 19: 77-81, Beijing.

Riall, J. A. (2004): Abrupt climate change: Chaos and order at orbital and millennial scales. - Global Planet. Change 41: 95-109, Amsterdam.

Rohling, E. J. (1991): Shoaling of the eastern Mediterranean pycnocline due to reduction of excess evaporation: implications for sapropel formation. - Paleoceanography 6: 747-753.

SADLER, P.M. (1994): The expected duration of upward-shallowing peritidal carbonate cycles and their terminal hiatuses. - GSA Bull. 106: 791-802, Boulder.

SALVADOR, A. (ed.) (1994): International Stratigraphic Guide - a guide to stratigraphic classification, terminology, and procedure (2nd ed.). - Int. Union Geol. Sci. and Geol. Soc. Amer., 214 p.

Schmitz, M. D., V. I. Davydov, W. S. Snyder, J. Ramezani \& S. A. Bowring (2005): New ID-TIMS $\mathrm{U}-\mathrm{Pb}$ zircon ages for the Carboniferous-Permian boundary sections of the southern Urals Russia, Kazakhstan. - Goldschmidt Conference Abstracts 2005, High-Precision Geochronology: A326.

Schulz, M. \& C.SchäFER-Neth (1998): Translating Milankovitch climate forcing into eustatic fluctuations via thermal deep water expansion: a conceptual link. - Terra Nova 9: 228-231, Oxford.

SChwarzacher, W. (1947): Über die sedimentäre Rhytmik der Dachsteinkalkes von Lofer. - Verh. Geol. Bundesanstalt, H10-12: 175-188.

SChwarzacher, W. (1993): Cyclostratigraphy and the Milankovitch theory. - Dev. Sedimentol. 52: 225 p., Amsterdam.

Shackleton, N.J., T. K. Hagelberg \& S. J. Crowhurst (1995): Evaluating the success of astronomical tuning - pitfalls of using coherence as as criterion for assessing pre-Pleistocene time scales. - Paleoceanography 10: 693-697, Washington.

ShACKLETON, N.J. \& N.D. OpDYKe (1973): Oxygen isotope and palaeomagnetic stratigraphy of Equatorial Pacific core V28-238: oxygen isotope temperatures and ice volumes on a $10^{5}$ year and $10^{6}$ year scale. - Quat. Res. 3: 39-55, Washington.

STRASSER, A. (1991): Lagoonal-peritidal sequences in carbonate environments: autocyclic and allocyclic processes. In: Einsele, G., W. Ricken \& A. Seilacher (eds.): Cycles and events in stratigraphy. - Springer-Verlag: 709-721, Heidelberg.

Strasser, A. \& H. HillgärTnER (1998): High-frequency sea-level fluctuations recorded on a shallow carbonate platform (Berriasian and Lower Valanginian of Mount Salève, French Jura). Eclogae Geol. Helv. 91: 375-390, Basel.

Strasser, A., B. Pittet, H. Hillgärtner \& J.-B. Pasquier (1999): Depositional sequences in shallow carbonate-dominated sedimentary systems: concepts for a high-resolution analysis. - Sed. Geol. 128: 201-221, Amsterdam. 
Strasser, A., H. Hillgärtner, W. Hug \& B. Pittet (2000): Third-order depositional sequences reflecting Milankovitch cyclicity. Terra Nova 12: 303-311, Oxford.

StrRAsSer, A., H. Hillgärtner \& J.-B. PAsquier (2004): Cyclostratigraphic timing of sedimentary processes: an example from the Berriasian of the Swiss and French Jura Mountains. - SEPM Spec. Publ. 81: 135-151, Tulsa.

Strasser, A. \& E. Samankassou (2003): Carbonate sedimentation rates today and in the past: Holocene of Florida Bay, Bahamas, and Bermuda vs. Upper Jurassic and Lower Cretaceous of the Jura Mountains (Switzerland and France). - Geol. Croatica 56: 1-18, Zagreb.

Tuenter, E. (2004): Modelling orbital induced variations in circum-Mediterranean climate. $-\mathrm{PhD}$ thesis, 147 pp. (http://www.knmi.nl/onderzk/phd/tuenter.pdf).

Tzedakis, P. C., J. F. McManus, H. Hooghiemstra, D. W. Oppo \& T. A. Wijmstra (2003): Comparison of changes in vegetation in northeast Greece with records of climate variability on orbital and suborbital frequencies over the last 450000 years. - Earth Planet. Sci. Lett. 212: 197212, Amsterdam.

Vail, P. R., F. Audemard, S. A. Bowman, P. N. Eisner \& C. Perez-Cruz (1991): The stratigraphic signatures of tectonics, eustasy and sedimentology - an overview. In: EINSELE, G., W. Ricken \& A.SeIlacher (eds.): Cycles and events in stratigraphy. - Springer-Verlag: 617-659, Heidelberg.

Van Assen, E., K. F. Kuiper, W. Krijgsman, F. J. Sierro \& N. Barhoun (2006): Messinian astrochronology of the Melilla Basin: stepwise restriction of the Mediterranean-Atlantic connection through Morocco. - Palaeogeogr., Palaeoclimatol., Palaeoecol. 238: 15-31, Amsterdam.

Van der Laan, E., E. Snel, E. De Kyrenel, F. J. Hilgen \& W. Krijgsman (2006): No major deglaciation across the Miocene-Pliocene boundary: Integrated stratigraphy and astronomical tuning of the Loulja sections (Bou Regreg area, NW Morocco). - Paleoceanography 21: PA 3011, Washington.

Van Vugt, N., J.Steenbrink, C. G. Langereis, F. J. Hilgen \& J. E. Meulenkamp (1998): Magnetostratigraphy-based astronomical tuning of the early Pliocene lacustrine sediments of Ptolemais (NW Greece) and bed-to-bed correlation to the marine record. - Earth Planet. Sci. Lett. 164: 535551, Amsterdam.

Van Wagoner, J.C., R.M.Mitchum, K. M. Campion \& V.D.Rahmanian (1990): Siliciclastic sequence stratigraphy in well logs, cores, and outcrops. AAPG Methods in Explor. 7: 55 pp., Tulsa.

VAradi, F., B. Runnegar \& M. Ghil (2003): Successive refinements in long-term integrations of planetary orbits. - Astrophys. J. 592: 620-630.

Vincent, B., C. Rambeau, L. Emmanuel \& J.-P. Loreau (2006): Sedimentology and trace element geochemistry of shallow-marine carbonates: an approach to paleoenvironmental analysis along the Pagny-sur-Meuse section (Upper Jurassic, France). - Facies 52: 69-84, Erlangen.

Wade, B.S. \& H.PäLIKE (2004): Oligocene climate dynamics. - Paleoceanography 19: PA4019, Washington.

Wanless, H.R. \& F.P.Shepard (1936): Sea level and climatic changes related to late Paleozoic cycles. - GSA Bull. 47: 1177-1206, Boulder.

Wanless, H. R. \& J. M. Weller (1932): Correlation and extent of Pennsylvanian cyclothems. - GSA Bull. 43: 1003-1016, Boulder.

Weedon, G. P. (2003): Time-series analysis and cyclostratigraphy. - Cambridge Univ. Press, 274 p., Cambridge.

Weedon, G.P. \& H.C. Jenkyns (1999): Cyclostratigraphy and the Early Jurassic timescale: data from the Belemnite Marls, Dorset, southern England. - GSA Bull. 111: 1823-1840, Boulder.

Wehausen, R. \& H.J. Brumsack (2000): Chemical cycles in Pliocene sapropel-bearing and sapropel-barren eastern Mediterranean sediments. - Palaeogeogr., Palaeoclimatol., Palaeoecol. 158: 325352, Amsterdam.

Westphal, H., M.J. Head \& A. Munnecke (2000): Differential diagenesis of rhythmic limestone alternations supported by palynological evidence. - J. Sed. Res. 70: 715-725, Tulsa. 
Williams, G.E. (1991): Milankovitch-band cyclicity in bedded halite deposits contemporaneous with Late Ordovician-Early Silurian glaciation, Canning Basin, Western Australia. - Earth Planet. Sci. Letters 103: 143-155, Amsterdam.

Williams, G. E. (2000): Geological constraints on the Precambrian history of Earth's rotation and the Moon's orbit. - Rev. Geophysics 38: 37-59, Washington.

Ziegler, P. A. (1988): Evolution of the Arctic-North Atlantic and the western Tethys. - AAPG Mem., 43: 198 p., Tulsa.

ZüHLKE, R. (2004): Integrated cyclostratigraphy of a model Mesozoic carbonate platform - the Latemar (Middle Triassic, Italy). - SEPM Spec. Publ. 81: 183-211, Tulsa.

\section{Glossary}

\section{Astronomy}

Aphelion: point on the Earth's (but also a planet's or comet's) orbit farthest away from the Sun.

Astronomical solution: analytical or numerical solution of the Solar System, which takes the Sun, Moon, Earth and other planets into account to calculate past variations in the Earth's orbital parameters and, hence, insolation.

Cardinal points: The summer and winter solstices and vernal and autumnal equinoxes. Together the cardinal points define the four seasons.

Earth's orbital parameters: the three parameters of eccentricity, obliquity and precession, which define the shape of the Earth's orbit (eccentricity) and the orientation and inclination of its axis (obliquity and precession).

Earth's orbital (Milankovitch) cycles: the three orbital cycles of eccentricity, obliquity and precession, which together determine changes in seasonal, latitudinal and global insolation received at the top of the atmosphere; these cycles are also termed Milankovitch cycles after the Serbian astrophyisicist Milutin Milankovitch.

Eccentricity: Eccentricity is the measure of the degree of elongation or ellipticity of the Earth's orbit, which varies between nearly zero (circular orbit) and 0.06 (slightly elliptical) and has main periods of $\sim 100$ and $\sim 400 \mathrm{kyr}$.

Equinoxes (Latin: equal night): the times of the year (around March 21 and September 21) when the Sun passes directly above the equator and is located perpendicular to it. During an equinox, day and night have equal duration everywhere on Earth.

Obliquity: Obliquity describes the angle between the Earth's axis of rotation and the orbital plane and varies between $22^{\circ}$ and $25^{\circ}$ with a main period around $41 \mathrm{kyr}$ (present-day value).

Peribelion: point on the Earth's (but also a planet's or comet's) orbit closest to the Sun.

Precession: Axial or astronomical precession is the slow movement of the rotation axis around a circular path with one revolution relative to the stars completed every 26,000 years. Due to the opposite movement of the eccentric orbit itself, the precession of the equinoxes relative to perihelion and aphelion - also called climatic precession - completes one full cycle with main periods around 19 and $23 \mathrm{kyr}$ (present-day values).

Solstices: the summer (winter) solstice is the moment when the Earth is at a point on its orbit where a hemisphere is most inclined towards (away) from the Sun, in other words, those moments of the year when the Sun reaches its southernmost or northernmost position, at the tropics.

\section{Geology}

Astrocycle: unequivocal term that exclusively designates orbital-induced sedimentary or geochemical cycles.

Astronomical Time Scale (ATS): Geological time scale with absolute ages based on the tuning of sedimentary cycles and other cyclic variations to astronomical target curves. 
Astronomical Polarity Time Scale (APTS): Polarity Time Scale with ages based on the astronomical tuning of cyclic sections having a magnetostratigraphy. For the younger part of the time scale the magnetostratigraphy should be calibrated to the reversal pattern observed in seafloor anomaly profiles.

Astronomical (orbital) tuning: the correlation, or tuning, of sedimentary cycles or other cyclic variations in climate proxy records to astronomical target curves of eccentricity, precession and obliquity or derived insolation time series; in principle the tuning provides accurate numerical ages for astrocycles and associated bio-events and magnetic reversals.

Climate proxy: parameter or index measured to estimate the value of a true climatic parameter such as sea-surface temperature (SST) in the past. As such it does not directly measure SST itself but provides a good approximation. Proxy indicators should preferably be calibrated against modern instrumental data to produce a good quantitative estimate of past climate.

Cyclostratigraphy: Subdiscipline of stratigraphy that deals with the identification, characterization, correlation, and interpretation of cyclic (periodic or quasi-periodic) variations in the stratigraphic record and, in particular, with their application in geochronology by improving the accuracy and resolution of time-stratigraphic frameworks.

Cyclothem: Term originally applied to a distinctive series of beds deposited during a single sedimentary cycle of the type that prevailed during Pennsylvanian time, later determined to be of glacial-eustatic origin. Most readily recognized cyclothems are marine units separated by terrestrial deposits or exposure surfaces. Thus the term is best applied to the shelf manifestation of a transgressive-regressive unit (or stratigraphic sequence) that resulted from glacial eustasy. With more detailed study a cyclothem can be traced into both basinal marine and terrestrial settings.

Floating Astronomical Time Scale: relative astronomical time scale based on the identification and number of astrocycles. The number of cycles is used to determine the duration, not the age, of an interval such as a polarity zone, a biozone or a stage. A floating time scale can be linked to a radiometric age determination for numerical calibration.

Milankovitch frequency band: The frequency range corresponding to the main periods of the Earth's orbital cycles and ranging from $\sim 15$ to $\sim 400 \mathrm{kyr}$.

Sub-Milankovitch frequency band: The frequency range having higher frequencies than the Milankovitch cycles but still within the millennial range. The range corresponds to periods between $\sim 1$ and $\sim 15 \mathrm{kyr}$.

Sapropel: dark-coloured, commonly laminated sediment rich in organic material deposited under suboxic or anoxic conditions.

\section{Statistics}

Bandpass filter: A filter that passes one band of frequencies and rejects both higher and lower frequencies. The filter is characterized by a centre frequency and by two cut-off frequencies, which determine the bandwidth of the filter. The filtered frequency signal can be represented in the time domain via inverse techniques and shown as an overlay on the initial time series to reveal at what time the spectral component (or cycle) is present in the time series.

Cross-spectral analysis: Cross-spectral analysis calculates 1) the power spectra of two time series, 2) the coherency spectrum showing the coherence between frequency components in the two time series having the same frequency, and 3) the phase spectrum showing the phase relation between components with the same frequency. Used to calculate lags and leads between different components of the climate system.

Fourier (Spectral) analysis: statistical method of decomposing a time series in the time domain into individual frequency components (sinusoids) and represent them in the frequency domain in the form of a spectrum by means of a Fourier Transform. Spectral analysis not only computes the frequency spectrum and the power of the spectral peaks but also determines phase. The latter is used in cross-spectral analysis. 
Spectrum and spectral peaks: graphic representation of a time series in the frequency domain with spectral power on the $y$-axis and frequency on the $x$-axis. Individual frequency components that are present in the time series show up as (spectral) peaks, which can be tested for significance.

Wavelet analysis: uses wavelets to decompose a time series into different frequency components, but each component is analysed with a resolution ("window") matched to its scale. The information is presented in the time and frequency domain at the same time, namely as a time-frequency representation of the signal.

Windowed Fourier analysis: uses a sliding window along a time series to calculate the spectrum after each time step. Successive spectra can be plotted in temporal order as a moving (evolutive) spectrum with time on the $\mathrm{z}$-axis. The effect of the window is to localize the frequency components in time but, in contrast to wavelet analysis, the width of the time-frequency window is fixed.

Typescript received 20.10.2006. 